THE ROLE OF THE GONOMEDUSA AND GONANGIUM IN THE SEXUAL REPRODUCTION (FERTILIZATION) OF THE HYDROZOA

$\operatorname{AUTHOR}(S)$ :

Miller, Richard L.

CITATION:

Miller, Richard L.. THE ROLE OF THE GONOMEDUSA AND GONANGIUM IN THE SEXUAL REPRODUCTION (FERTILIZATION) OF THE HYDROZOA. PUBLICATIONS OF THE SETO MARINE BIOLOGICAL LABORATORY 1973, 20: 367-400

ISSUE DATE:

1973-12-19

URL:

http://hdl.handle.net/2433/175769

RIGHT: 


\title{
THE ROLE OF THE GONOMEDUSA AND GONANGIUM IN THE SEXUAL REPRODUCTION (FERTILIZATION) OF THE HYDROZOA
}

\author{
RICHARD L. MILLER \\ Department of Biology, Temple University, Philadelphia, Pennsylvania 19122 \\ and
}

The Marine Biological Laboratory, Woods Hole, Massachusetts 02543

With 19 Text-figures

\begin{abstract}
Introduction
Much polyp specialization of function occurs within the group hydroida, such that defensive, nutritive, sexual, and other polyp forms may be found on the same colony. The sexual individual is specialized for the asexual production of one or more gonomedusae, ${ }^{1)}$ in which the gametes will appear, mature, and, in many cases, undergo fertilization and embryogenesis. The extent of the morphological completeness or elaboration of the gonomedusa varies widely among the hydroida, with complete spectra of form found in both the Thecata and Athecata. The spectrum in each group ranges from an almost total absence of visible medusoid characteristics, to a highly elaborate free-living medusa which may itself be capable of asexual production of new medusae. An immediate consequence of the reduction of medusoid characteristics is the relegation of the gonomedusa to a permanent or semi-permanent sessile existence. Instead of a structure designed to aid in mixing gametes prior to fertilization, or to at least remove the offspring to some point distant from the parent colony, the gonomedusa finds utility as a protective device for the maturing gametes at first, and in many cases, functions as both the site of fertilization and as a brooding chamber for the developing embryos.

One consequence of the production of sessile gonomedusae seems to be a tendency to bud them in groups. In the Athecata this is seen in the form of special non-feeding "sexual" polyps (as in Hydractinia or Eudendrium), or in grouped budding such as the racemes of Tubularia. In the Thecata, related groups of gonomedusae are sequestered by the theca in special structures called gonangia. These can be considered "sexual" polyps, equivalent in form and function to the gonozoid of Hydractinia, for example.
\end{abstract}

1) Unless otherwise indicated, the term "gonomedusa" will be used to designate all hydrozoan sexual reproductive structures, whatever the level of anatomical organization. 
Grouping of gonomedusae in gonangia, particularly when the gonomedusae are sessile, has been accompanied by an elaboration of both the somatic tissues of the gonangium and the acellular theca. In some cases, such as Aglaophenia, even gonangia are produced in groups, and polyps and even whole branches of the colony may be brought into play as structural additions to protect the gonangia.

Sexual dimorphism is strongly in evidence in the sessile gonomedusae of many hydroids. Functionally, the roles of the two sexes in hydroids may be similar or divergent, depending in large part on the extent of development of the brooding habit in the species in question. In all males, the sperm are released into the sea water from the sessile gonomedusa, usually through an opening at the gonomedusa apex. In the thecates, this may be preceded by extrusion of the ripe gonomedusa from the gonangium apex. The major function of the male gonomedusa or gonomedusagonangium complex thus appears to be regulation of sperm release to the exterior. In the female, release of gametes to the exterior may occur as in the male (e.g., Campanularia gelatinosa) or the gametes may be sequestered in various ways prior to fertilization such that the developing embryos are protected until they become free-swimming planula larvae. The extent of protection afforded the embryos varies a great deal, from exposure to the external environment of eggs that are protected only by a mass of jelly to envelopment of the eggs within gonomedusa walls which in turn are enclosed by somatic gonangial tissues; the whole being retained inside a protective gonotheca composed of perisarc. In the latter case, as in the former, the protective devices developed as a consequence of the evolution of the brooding habit raise firm barriers to the penetration of spermatozoa and the subsequent fertilization of the eggs.

Brooding therefore requires the development of mechanisms which aid the penetration of the proper species spermatozoa into the gonangium and gonomedusa. The female sexual structure, besides protecting the developing embryo, must also act as an intermediary between egg and sperm. If this is the case, then specializations should exist, both anatomically and physiologically, for guidance of sperm to the egg, preparation of the sperm for interaction with the egg, and possibly for sequestering the sperm for long periods within the gonangium to await egg maturation. Further, whatever kind of sperm manipulation mechanisms exist, they require some level of specificity to prevent non-homologous sperm from interfering with normal development. The components of the gonomedusa and gonangium which could be utilized in one way or another to provide the chemical and morphological requisites for these functions are: the theca; the blastostyle nutritive endoderm complex; the ectoderm tissue which, depending on its location, both surrounds the eggs and secretes the gonotheca; the apical tentacular specializations of the gonomedusa; and the eggs themselves. It is the thesis of the following discussion of four examples of fertilization in hydroids possessing sessile gonomedusae, that much of the complexity of gonangial and gonomedusa morphology in females is the result of the development of sperm guidance mechanisms required to overcome the barriers to fertilization imposed by 
devices used to protect the developing embryos.

\section{Athecata: Gonomedusa Structure and Function}

\section{A. Cordylophora}

The early gonophore of both sexes of Cordylophora lacustris appears as a small endodermal invagination just proximal to a polyp (Fig. 1A, 2A). At this stage it can be distinguished from a polyp bud only by position but within 24-36 hours the endoderm (blastostyle) mass has formed lobes (Fig. 1A, 2B) which rapidly increase in size (Fig. 1C). The ectoderm forms a sheath over the endoderm as the blastostyle lobes extend to form branches (Fig. 1D). The gametes appear between the ectoderm and endoderm layers, being derived from the former according to WEISMANN (1883). In the male, maturation consists essentially of an increase in the mass of spermatocytes at the expense of the branched blastostyle. The structure of the blastostyle becomes diffuse with time, and it eventually disappears entirely, leaving a dense, white sperm mass within the ectodermal remnant (Fig. 1E, F). The ectoderm, in the later stages of maturation, secretes a thick periderm (outer coating) which encapsulates the gonomedusa except at the apex where there is formed a nipple-like structure that penetrates much of the acellular material, nearly reaching the exterior (Fig. 1F). It is through this structure that the sperm will be released to the outside.

In the female, the blastostyle remains well defined (Fig. 2B) until the oocytes have matured. By this time, however, it has lost much of its mass (Fig. 2C) and will eventually shrink to a remnant which makes up the gonomedusa stem. As a result of the shrinking, a cavity is formed in which the eggs rest, and it is within this cavity that fertilization and development of the embryos to the planula stage takes place. The ectoderm begins to lay down a thick jelly-like external coat at about the time the oocytes become visible within the blastostyle mass (Fig. 2B) and either by accretion or swelling the jelly increases massively in thickness (Fig. 2C). It is likely that the increase is due to swelling (uptake of water), since the ectoderm remains in contact with the shrinking blastostyle and therefore does not underlie parts of the jelly which will increase in thickness at a later time. The mature female gonomedusa (Fig. 2C) thus consists of a short stem filled with coenosarc, attached to which is a massive jelly sphere. The sphere contains a fluid-filled cavity of about half the diameter of the whole structure, and resting within the cavity are from four to as many as ten ova.

No visible micropyle-like opening has ever been seen in the external jelly layer. The layer is not homogeneous, however. Fine striations (Fig. 2C) can be seen extending through the inner portions of the layer in a radial direction from the cavity, and sometimes layering parallel to the external surface can be seen. A mature gonomedusa, the outer wall of which is composed entirely of a jelly-like substance, occurs in a number of other hydroids (e.g., Clava) including some thecate forms such as Campanularia urceolata (Fig. 17), and a number of species of Plumularia and Sertularia 

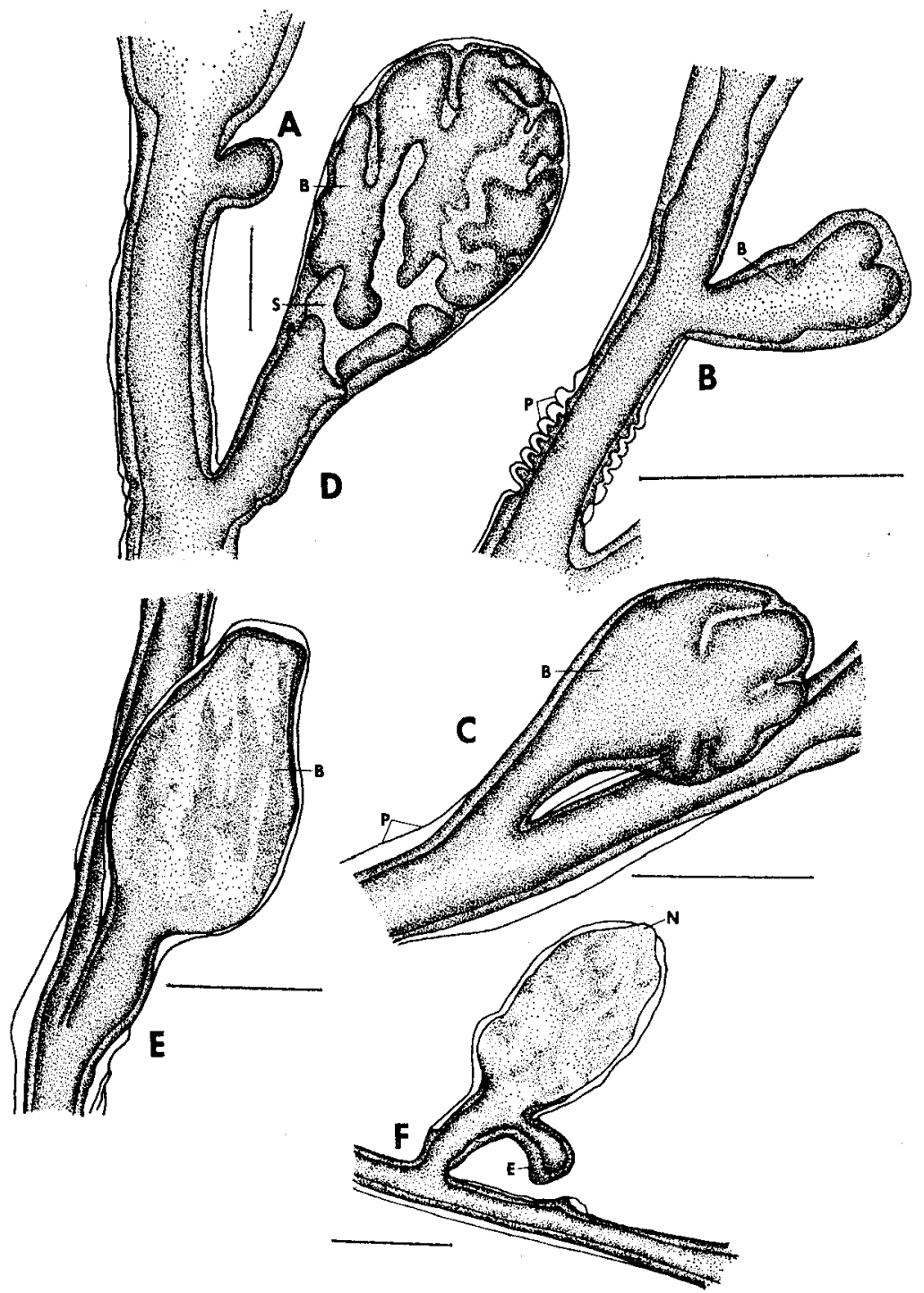

Fig. 1. Growth stages of the male gonomedusa of Cordylophora lacustris. A. Early bud. B. A stage approximately 19-20 hours older than A. C. Blastostyle beginning to branch. D. Sperm mass and a thickened perisarc appear. E. Nearly mature male. Blastostyle degenerating and sperm mass turning white. F. Mature male, with ectoderm withdrawn from the sperm mass and the apical protrusion penetrating the perisarc. Note the appearance of a stolon from the gonomedusa stem. Stolonic outgrowths like this are commonly found growing from spent gonangia of both sexes in culture. Culture conditions: $30 \%$ sea water at room temperature. Key: B, blastostyle; E, stolon; N, apical protrusion; $\mathrm{P}$, perisarc; $\mathrm{S}$, sperm mass. Each scale mark represents $0.5 \mathrm{~mm}$. 


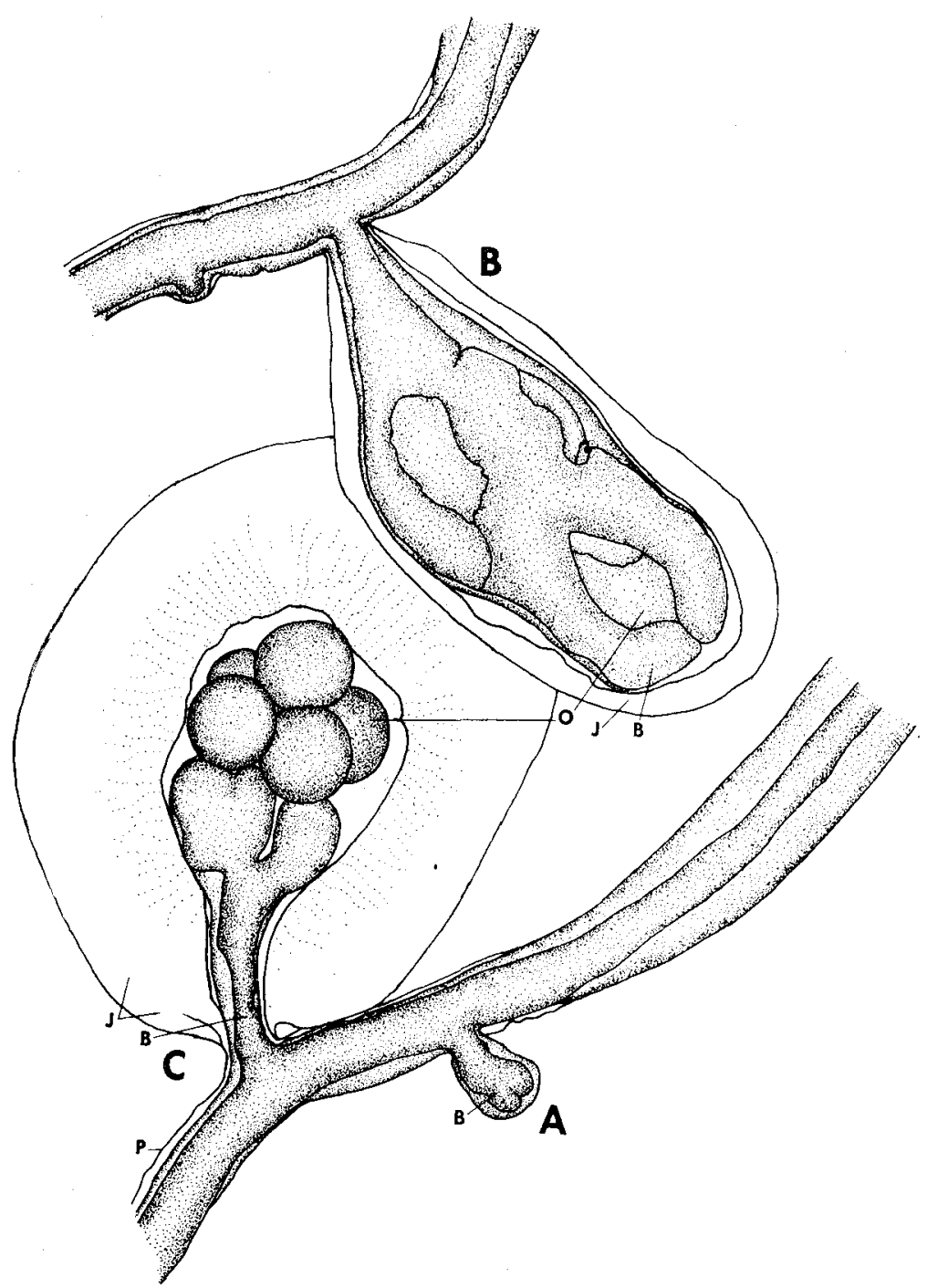

Fig. 2. Three stages in the development of the female gonomedusa of Cordylophora lacustris. A. Early bud, equivalent to stage B, Fig. 1. B. An almost mature female with a massive branched blastostyle within which is embedded a number of oocytes. Note the thickened perisarc and the beginnings of the appearance of a cavity between it and the apical portion of the blastostyle. A small bud, probably representing a very early stage of gonomedusa formation appears to the left of the stem of this female. C. A fully mature female gonomedusa containing mature or newly fertilized eggs. The blastostyle has decreased markedly in size, leaving a cavity containing the eggs. The jelly coat has increased at least $4-5$ folds in thickness over that of stage B, and fine, radially orientated striations exist over the inner half of the jelly. Key: B, blastostyle; $\mathrm{J}$, jelly layer; $\mathrm{O}$, egg; $\mathrm{P}$. perisarc. The scale mark represents $0.5 \mathrm{~mm}$. 
(Fig. 18). Such a structure appearing apically on a gonangium is called an acrocyst (Allman, 1863), and it appears that the mature female gonomedusa of Cordylophora is at least structurally an acrocyst.

Fertilization has not been observed in Cordylophora, but the penetration of the sperm into the mature female acrocyst has (Miller, unpublished). The sperm attach (evidently by chance) to the outer surface of the acrocyst wall and begin to bore inward, moving slowly through the jelly mass apparently without any directional guidance. The motile force is exerted by the anterior one-third of the flagellum which can be seen to be beating much in the manner of the flagellum of the sperm of Gonothyrea when attached to the tentacles of the female meconidium (MILleR, 1970; see below). The distal two-thirds of the flagellum appears to be dragged passively behind the sperm. The mechanism by which the head of the sperm is able to penetrate the acrocyst wall is unknown, but it seems that the sperm creates at least a temporary canal as it moves. Since the migration of the penetrating sperm does not appear to be directed inward ${ }^{2}$ ) it has been possible to observe sperm attempting to leave the outer surface of the acrocyst as well as those entering the internal cavity. Those leaving the acrocyst behave in the same way as the sperm of Gonothyrea that have reached the end of a meconidium tentacle (MILlER, 1970). The sperm extend such that the entire flagellum is free of the acrocyst surface except for the filamentous tip, which is evidently very sticky. Vigorous swimming movements, coupled with sharp bends of the flagellum may be made. The sperm may break free and swim off, or reattach if the head strikes the acrocyst surface, whereupon penetration of the acrocyst wall may begin again. Evidently, the inner and outer surfaces of the acrocyst wall differ in their stickiness for Cordylophora sperm since in no case was fiagellar adherence seen when sperm that had negotiated the entire thickness of the wall attempted to leave the inner surface. The separation was clean and rapid, normal active motility was initiated immediately, and the sperm soon became thigmotactic to the egg surface.

\section{B. Tubularia}

The gonomedusae of both sexes of Tubularia crocea, T. marina, and T. larynx are shown in Fig. 3. They are all rudimentary; lacking radial canals, but possessing, at least in the females, a well defined bell, bell opening surrounded by tentacles, and a large but non-functional manubrium (blastostyle or "spadix"). Large numbers of gonomedusae are budded from between the proximal and distal tentacles in the form of racemes which look like bunches of grapes. Sections showing the internal anatomical features of the male and female gonomedusa in Tubularia have been published by BENOIT (1925) and more recently for the females only by VAN DE VYVER (1968). In general, males lack well-defined tentacles and have a less massive spadix than

2) In colonies collected from the wild, ripe female gonomedusae are often found with a large number of sperm embedded in the acrocyst wall, distributed such that the majority are in the portion of the wall closest to the internal cavity. This may only reflect an increased density of the jelly in this zone, which would tend to trap sperm there. 
females, and the bell opening is less apparent. For excellent figures of male gonomedusa anatomy and development, see BENOIT, 1925, pp. 198-203. In both sexes, particularly in $T$. larynx, the medusa bells display active pulsations, especially when under temperature stress, and may expel both ripe and immature gametes under such conditions. To a large extent, the structural pattern of the gonomedusae seen in Tubularia is like that of the meconidia of Gonothyrea (see section IIA). Both fertilization and embryogenesis take place up to the larval stages within the gonomedusae of both genera.

The problem of sperm approach and entry into the gonomedusae of Tubularia has been considered by MILLER (unpublished). Observation of sperm in the vicinity of gonomedusae carrying ripe ova reveal that the sperm motility and direction are affected only at the apex of the gonomedusa. In favorable situations aggregations
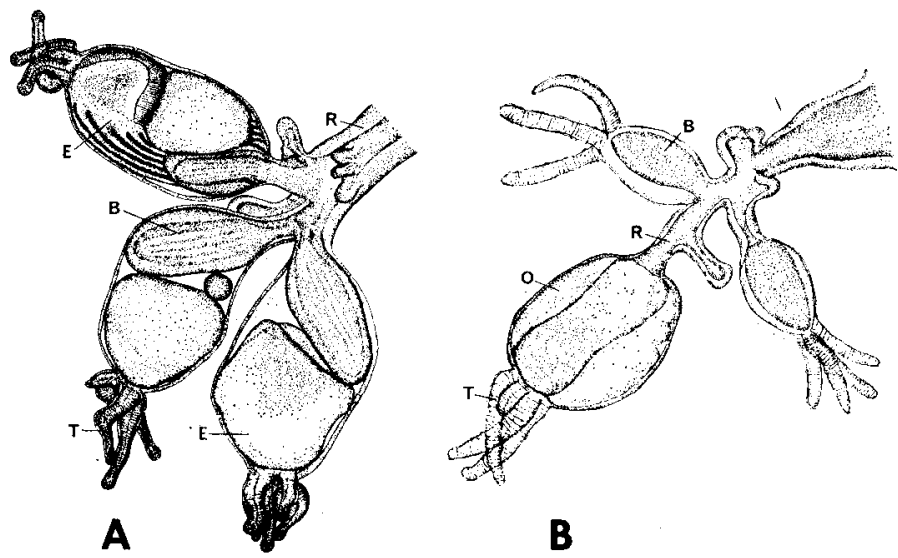

B

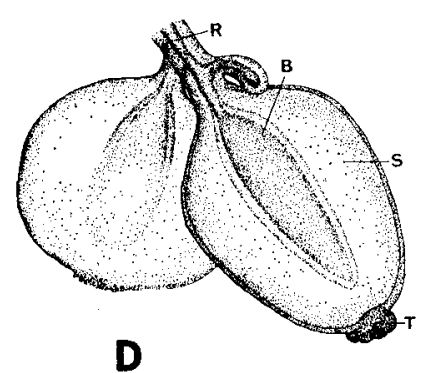

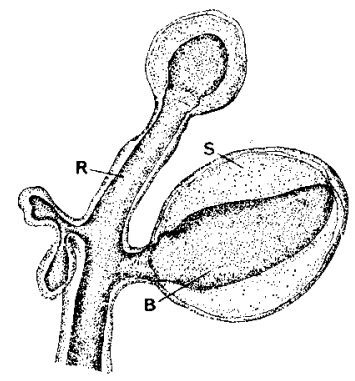

$\mathbf{E}$
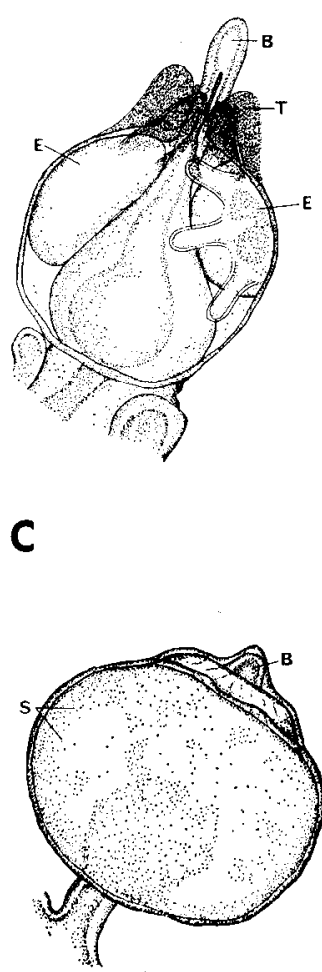

$\mathbf{F}$

Fig. 3. Male and female gonomedusae of Tubularia larynx, Tubularia marina, and Tubularia crocea. A. Female gonomedusae of $T$. larynx. B. Half-grown and fully ripe male gonomedusae of $T$. larynx. C. Female gonomedusa of T. marina. D. Male gonomedusae of T. marina. E. Female gonomedusa of $T$. crocea bearing two embryos. Note the characteristic eight blade-like tentacles surrounding the apically protruding blastostyle. F. A nearly ripe male gonomedusa of $T$. crocea. Key : B, blastostyle; E, embryo; O, egg; R, raceme; S, sperm mass; T, tentacles. (From MiLlER, 1972a, with permission). 
of motile sperm form at the base of the small cluster of short tentacles found here (Fig. 3 A,C,E), but in no case were sperm seen to adhere to or migrate along the surface of the tentacles. Sperm entry into the gonomedusa is by way of the bell opening, through which, particularly in the case of $T$. crocea, the blastostyle may protrude (Fig. 3E). It is not known if the attractant responsible for the sperm aggregations is released by the cells surrounding the bell opening, or is emanating from some internal structure, such as the eggs, blastostyle, or the thin ectoderm layer surrounding the eggs VAN DE VYVER (1968). Sperm have been seen to penetrate the gonomedusa opening and appear to swim normally once inside (MILlER, unpublished). The figures in VAN DE VYVER (1968) indicate that once inside the cavity of the gonomedusa, the sperm face at least one tissue barrier to direct access to the egg surface.

\section{Thecata: Gonomedusa and Gonangium Structure and Function}

\section{A. Gonothyrea}

The gonangium of both sexes of Gonothyrea loveni (Fig. 4) is of a shape much like that of C.flexuosa (Fig. 6). The gonotheca is tubular (narrower in males than females)

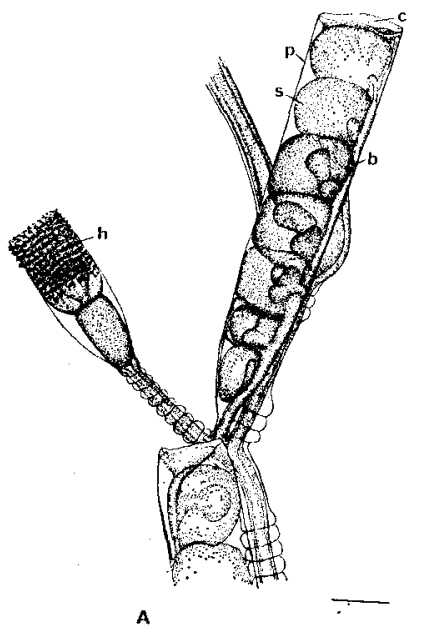

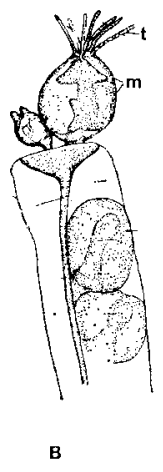

C

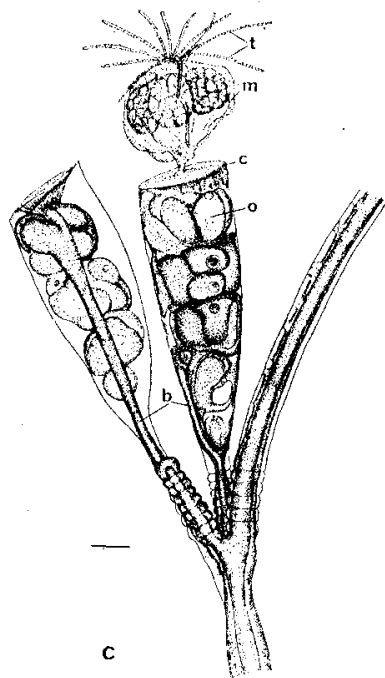

Fig. 4. A. Portion of a male colony of Gonothyrea loveni bearing two gonangia. Neither is mature, but both are at a stage just prior to extrusion of the first meconidium. B. The upper portion of a mature male gonangium which has extruded two meconidia, one of which has expelled most of the sperm. C. A portion of a female colony of $G$. loveni bearing two gonangia. One is still immature, while the other bears one meconidium containing embryos in the "morula" stage. The uppermost meconidium within this gonangium is ready to be extruded. Key: b, blastostyle; c, blastostyle cap; h, hydranth (contracted); m, meconidium; $\mathrm{o}$, egg; $\mathrm{p}$, perisarc or gonotheca; $\mathrm{s}$, sporosac of the male; $t$, tentacle of meconidium. Scale for $A, B=0.2 \mathrm{~mm}$; for $C=0.1 \mathrm{~mm}$. (From Miller, 1970). 
and blunt at the distal end, having the over-all shape of a tapered cone. The relationship of the gonomedusae to the blastostyle is the same as in C. flexuosa (see section IIB) although, at least in males, the gonomedusae in Gonothyrea all bud out on the same side of the blastostyle, forcing it to one side of the gonotheca as they enlarge and move distally. The pre-maturation form of the blastostyle is also similar to C. flexuosa, the gonangium elongating for a considerable length of time and the blastostyle cap which secretes the gonotheca remaining a prominent component of the structure. However, the cap in both sexes shrinks markedly in both thickness, and, to a lesser extent, in diameter, as the gonangium nears maturation. Thus, the elaborate transformation of the cap into a distal opening and "funnel" which is found in C. flexuosa female gonangia (MrLLER, 1969) does not occur in this species. Instead, the mature or nearly mature gonomedusae push out through the cap in the form of imperfect medusae, which remain attached in the female not only during maturation and fertilization of the eggs, but also for the entire course of embryonic development up to the free-swimming planula stage. These gonomedusae are called meconidia by Allman (1863).

The extruded meconidia of the two sexes are similar in structure but the female is larger and more elaborate. In both sexes, the germ cells rest on the endoderm (rudimentary blastostyle). WeismanN (1883) describes a thin ectoderm layer overlying the gametes in the mature female meconidium which holds the ripe eggs against the blastostyle (Fig. 8A). AlLman (1863) also shows this layer, which he calls an "endotheca". I have observed this layer also when trying to dissect ripe and germinal vesicle stage ova free of the meconidium. After the meconidium wall has been removed, the eggs often remain adherent to the blastostyle endoderm. Using fine forceps, a thin tissue layer can be stripped off the eggs after which they fall free of the endoderm. In the ripe male meconidium, the sperm mass often does not become uniformly motile. A layer of actively swimming sperm may then be seen between the inner wall of the meconidium and the mass of non-motile (presumably immature) sperm close to the blastostyle. It is likely that the boundary between the non-motile sperm and the motile cells consists of the same thin ectoderm layer found in the female meconidium. Partial activation of the sperm mass, with a clearly defined separation between the motile and non-motile cells, has also been observed in Tubularia larynx (Milcer, unpublished).

When mature, the meconidia of both sexes lack a functional manubrium, except for the apparently nutritive endoderm tissue which is often markedly reduced in size by the time the gametes have matured. The capsule containing the gametes is the medusa bell itself, at the apex of which is a small, clearly visible opening. In the male, the opening rim is slightly swollen and bears three or four short tentacles (Fig. 4). No radial canals exist in the bell. In the female, the tentacles are both more numerous and longer, and are more noticeably contractile than those of the male (Fig. 4). Often one or more nematocysts are present on a tentacle, but otherwise their surfaces are 

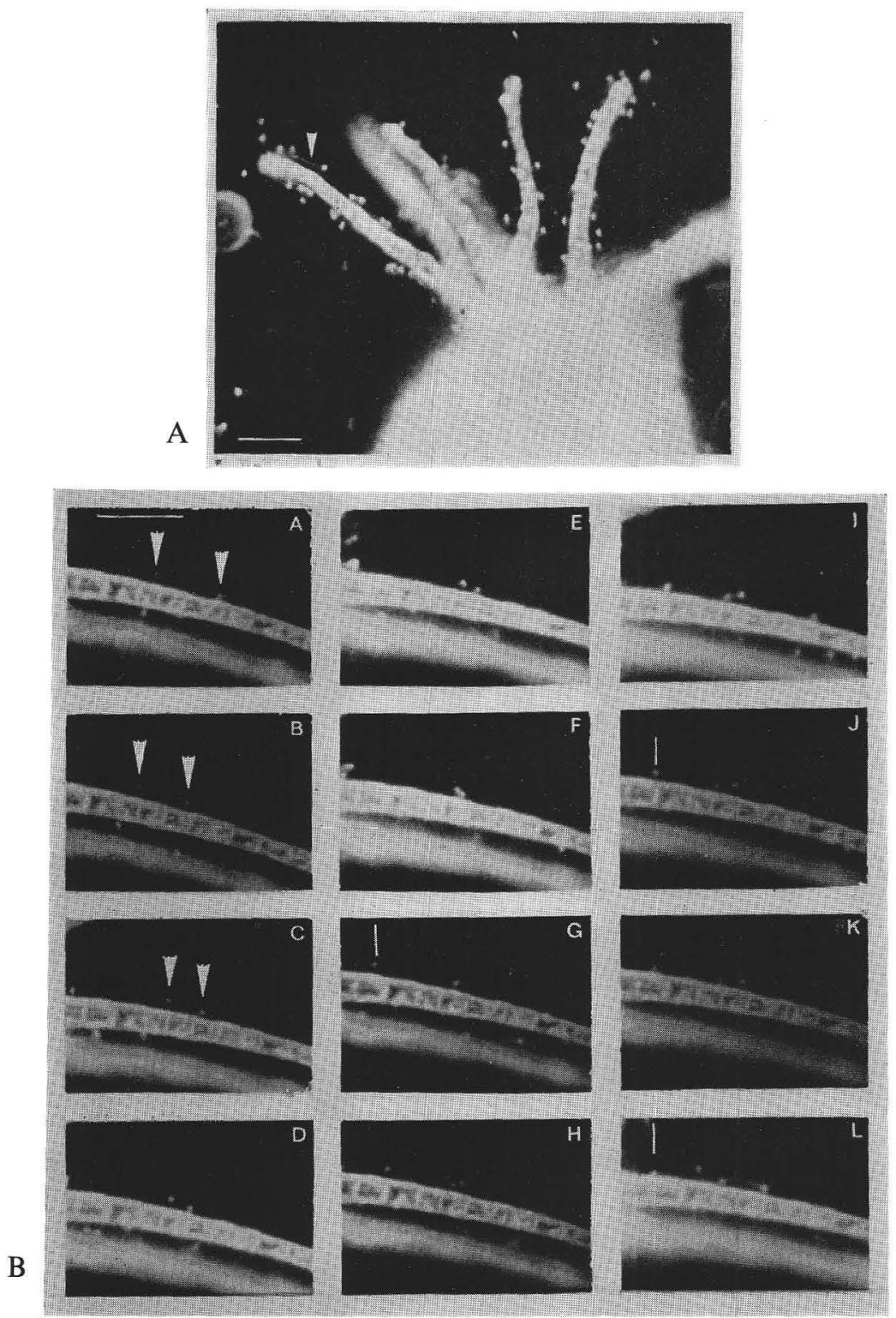

Fig. 5. A. A female meconidium of Gonothyrea loveni with sperm sticking and migrating on the tentacles. Note that the sperm heads and flagella (arrow) rest a short distance (approximately 2-4 mu) above the tentacle surface. Scale represents $30 \mathrm{mu}$. B. Two sperm (arrows) migrating on the surface of a Gonothyrea meconidium tentacle in opposite directions and passing each other without interference. $(\mathrm{E}, \mathrm{F}, \mathrm{G}, \mathrm{H})$. The sperm on the right in frame $\mathrm{A}$ is moving at about $12 \mathrm{mu} / \mathrm{sec}$., while that on the left is moving at about $6 \mathrm{mu} / \mathrm{sec}$. A third sperm (white lines in $\mathrm{G}, \mathrm{J}$ and $\mathrm{L}$ ) can be seen making a reverse turn on the tentacle surface resembling turning seen at the tentacle tip. The scale in frame A equals $30 \mathrm{mu}$. (From Miller, 1970). 
smooth. The opening into the bell is usually more prominent than that of the male and radial canals, though often incomplete, extend from the attachment stalk toward the bell margin. In contrast to the more rudimentary female gonomedusa of Campanularia, which always bears a single egg, the female meconidium of Gonothyrea may bear as many as eight.

It seems clear from the above description that both male and female meconidia can serve equally well for bearing and protecting gametes, though the female tends to be more massive since it serves as an incubator for the rather bulky developing larvae. Spent female and male meconidia both survive considerably longer than the 4 days required for development from the fertilized egg to a planula (at $14^{\circ} \mathrm{C}$.). The better developed tentacular apparatus of the female thus appears to be a consequence only of the greater size of the female required for the incubation of the developing embryos. That defense is not the function of the tentacles is indicated by the almost total lack of nematocysts.

Miller (1970) has shown that the tentacles in fact serve as sperm traps and possibly as contact guidance pathways in conjunction with a chemo-attractant released near the base of the tentacles (MILLER, 1970b, 1972b) or through the opening of the meconidium bell. Gonothyrea sperm adhere strongly to the meconidium tentacles by their flagella and are capable of slow migration over the surfaces of the tentacles in both directions (Fig. 5B). A jelly-like material appears to coat the tentacle surface (Fig. $5 \mathrm{~A}$ ), and it is on or within this matrix that the sperm move. The sperm of Campanularia calceolifera are also capable of adhering to and migrating along Gonothyrea meconidium tentacles, but the sperm of Campanularia flexuosa or Tubularia do not stick at all (MILLER, 1970b). Sperm entering the female meconidium swim normally inside bell and fertilization takes place there. As in Tubularia, the thin ectoderm layer surrounding the eggs presents a final barrier to sperm access to the egg surface.

\section{B. Campanularia}

Two genera, Campanularia flexuosa and Campanularia calceolifera have been used extensively for studies of sperm chemotaxis to the female gonangium (MILLER, 1966). The gonangia of both sexes of these species are tubular in shape and grow to maturity in a fashion similar to that described for C. flexuosa (see below and Miller, 1969). The basic construction is best exemplified by the male gonangium of C.flexuosa (Fig. 6B) which consists of a central blastostyle that extends distally into a mushroom-shaped cap. In the immature stage (Fig. 7A) this cap is relatively large and as the gonangium grows, the blastostyle lengthens, carrying the cap distally, the edges of the cap laying down a perisarc tube (MILleR, unpublished). As the gonangium nears maturity, the cap dwindles in both thickness and diameter, such that the perisarc tube narrows distally (Fig. 7B,C). The blastostyle itself buds laterally when the gonangium is still young, producing a series of outpocketings of endoderm around which the early germ cells are located. Presumably the germ cells act as inductive agents in the process, but nothing is known about this. The outpocketings appear sequentially, with the oldest 

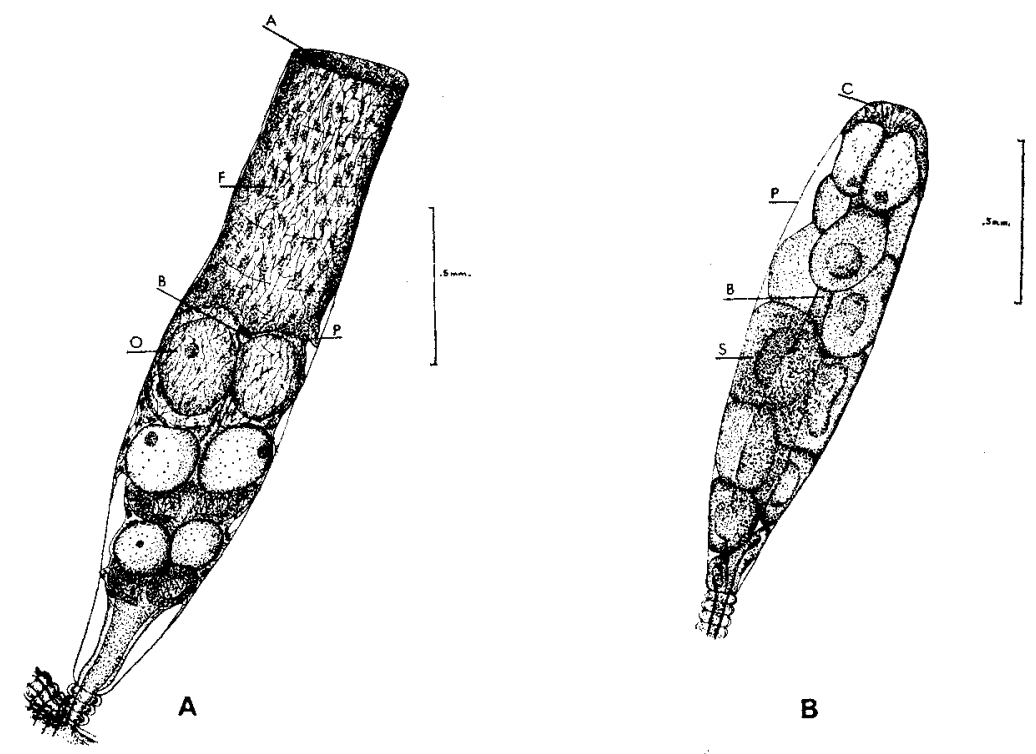

B

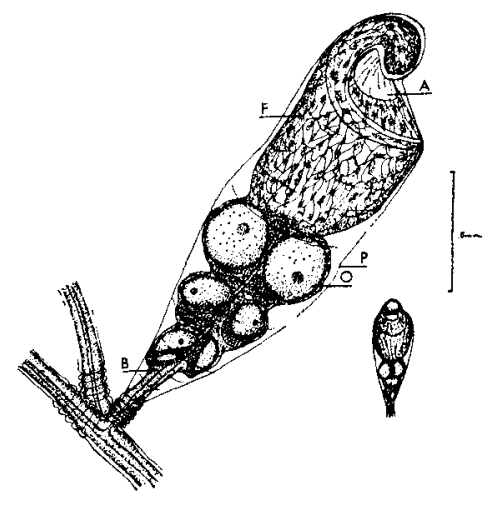

C

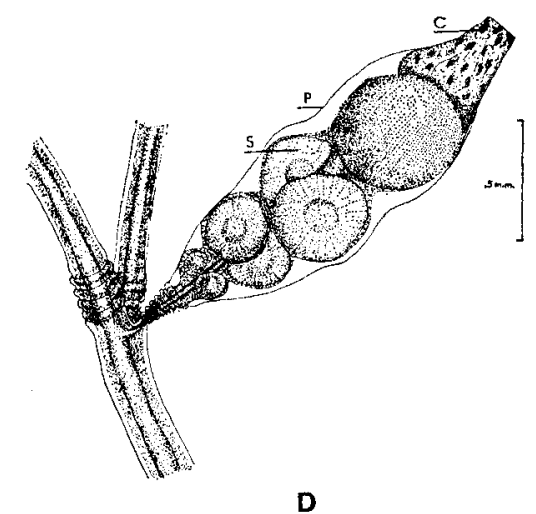

D

Fig. 6. A. Mature female gonangium of Campanularia flexuosa. B. Male gonangium of $C$. flexuosa before extrusion of a ripe gonomedusa (sporosac). C. Mature female gonangium of C. calceolifera. D. Nearly mature male of C. calceolifera. Key: A, aperture of female; B, blastostyle; C, blastostyle cap of the male; F, funnel tissue of the female; $\mathrm{O}$, ovum surrounded by proximal ectoderm; $\mathrm{P}$, perisarc or gonotheca; $\mathrm{S}$, male sporosac, The scale marks represent $0.5 \mathrm{~mm}$. (From Miller, 1966). 
appearing first and moving distally. Younger buds appear proximally as the gonangium elongates. By the time the gonangium ceases to elongate, the most distal of them bears mature spermatozoa and proximal budding is completed (Fig. 7C). When the spermatozoa of the most distal gonomedusa are mature, the gonomedusa pushes or is pushed through the distal cap to the outside, where it will eventually burst, releasing the sperm (Fig. 7C). WEISMANN (1883) has defined reduced gonomedusae appearing within gonangia as sporosacs, a term which will be adopted in this discussion.

During the growth of the male sporosac and the maturation of the contents, it can be seen that the endodermal core becomes central in position and almost disappears by the time the sporosac is ready to release the spermatozoa. WEISMANN (1883) has
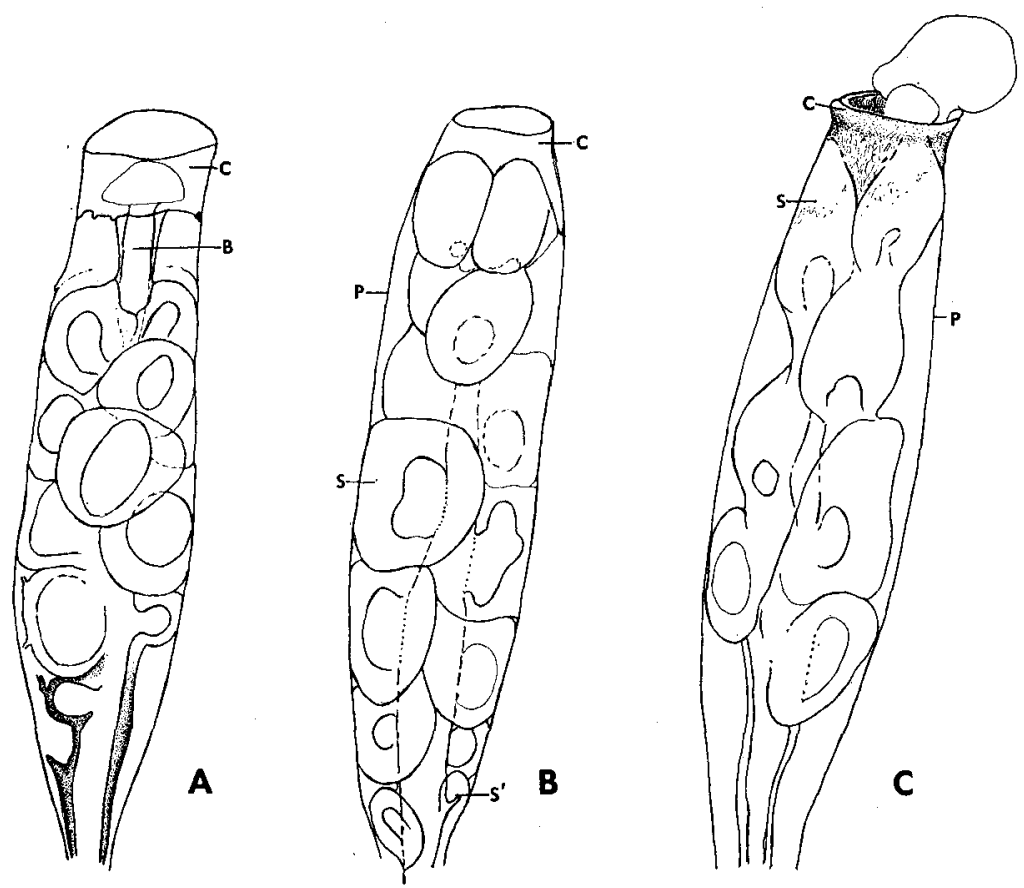

Fig. 7. Three stages late in the development of the male gonangium of Campanularia flexuosa. A. Prior to maturation with the cap intact and secreting perisarc. New gonomedusa (sporosac) buds appearing at the proximal end of the blastostyle. B. Nearly mature. The cap has thinned considerably and the uppermost sporosacs are elongating in the direction of the long axis of the blastostyle. New sporosac buds are still present proximally. C. Mature gonangium, which has extruded two sporosacs. The structure of the blastostyle cap has become diffuse and the sporosacs below the cap have elongated markedly in the long axis of the blastostyle and have turned bright white. No new sporosac buds have appeared at the proximal end of the blastostyle since stage B and the movement of the older spososacs distally is evident. Key: B, blastostyle; C, blastostyle cap; P, perisarc or gonotheca; S, sporosac or gonomedusa; S', sporosac bud. 
provided a brief description of the contents of the male sporosac during early development (Fig. 8D). The sporosac is encased in ectoderm which is derived from the blastostyle ectoderm (outer) and entocodal ectoderm (inner). The germ cells rest directly on the endoderm core. LUNGER (1971) reports that the most immature spermatocytes reside next to the "sporosac lumen", which is probably the gastrovascular cavity of the endodermal core (blastostyle branch). Maturing spermatids lie just beneath the mesogloea, which separates them from the entocodon-derived "manubrial" ectoderm (subumbrella ectoderm) (WEISMANN, 1883), and are surrounded by strands of endodermal tissue which are, presumably, both supportive and nutritive in character.

In the female (Fig. 6A), the general structural plan of the gonangium is similar to that of the male, differing, however, in some important details. A central blastostyle and a distal cap are present, but the cap is both thicker and wider than that of the male and remains a prominent characteristic of the immature gonangium until it undergoes the rather marked and rapid morphological reorganization accompanying maturation of the gonangium (MILler, 1969) (Fig. 9). Since the cap is larger, the size of the perisarc tube is larger, being both wider and longer than that of the male. In one series of measurements, for example, the length reached by a group of female gonangia was one-third greater than that reached by males grown under the same conditions. Lateral outpocketings appear from the proximal end of the blastostyle as in the case of the male, but a single oocyte replaces the mass of spermatocytes. The oocyte rests on the evaginated endoderm of the sporosac, which is much more massive than that found at any stage of sporosac development in the male. The oocyte pushes the endoderm to one side, usually proximal, of the sporosac, but remains in intimate
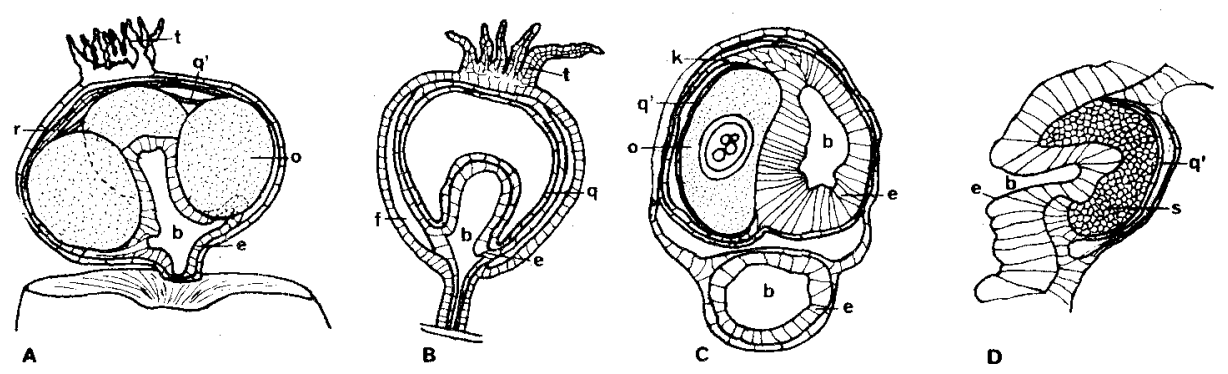

Fig. 8. Optical sections of gonomedusae of Gonothyrea loveni and Campanularia flexuosa. A. Female meconidium of $G$. loveni bearing three eggs. The apical tentacles are contracted in this specimen. B. Male meconidium (sterile) of $G$. loveni. C. Section of a female gonomedusa of $C$. flexuosa bearing an early oocyte. D. Section of a very young male gonomedusa of $C$. flexuosa bearing spermatogonia. Key: b, gastrovascular cavity of blastostyle; e, endoderm; $\mathrm{f}$, sectioning artefact; $\mathrm{k}$, "entodermlamella" (endoderm layer surrounding the oocyte in $C$. flexuosa); o, egg or oocyte; $\mathrm{q}$, entocodon tissue layer; $\mathrm{q}^{\prime}$, thin ectoderm layer which is probably derived from the inner entocodon layer; r, radial canal; S, spermatogonia. (All figures redrawn from WEISMANN, 1883). 
contact with it. More advanced oocytes, possessing prominent germinal vesicles, are positioned more distally along the blastostyle. By the time gonangium maturation begins, the most distal oocytes are close to maturation themselves, though it is at present unknown if any relationship exists between the morphogenesis of the distal cap to the mature state and the maturational divisions of the distal-most oocytes. By the time maturation of the eggs has occurred, the supporting endodermal masses have nearly disappeared, the mature eggs resting in a cavity at least the outer portions of which are composed solely of ectoderm (Fig. 6A).

The structure of the female sporosac has been investigated in some detail by O'RAND (1972a, unpublished) at the ultrastructural level. He finds that the mature oocyte prior to germinal vesicle breakdown is surrounded by an acellular matrix which is itself surrounded by a single layer of cells. WeISMANN (1883) (Fig. 8C) calls the cellular layer ectoderm. Surrounding this cell layer is a layer of endoderm ("entodermlamella") figured by Weismann, which is an extension of the blastostyle outpocketing on which the oocyte rests. It is likely that this layer is homologous with the endodermal strands that invade the spermatocyte mass in the male sporosac. These two cell layers are further surrounded by two ectoderm layers, one derived from the entocodon (subumbrellar ectoderm) and the other derived from the blastostylar ectoderm which, in combination with the outer portion of the entocodon layer, would normally form the medusa bell. Further layers may be added during gonangium maturation, as the result of proximal spreading of the cap ectoderm (see below). The egg remains within these layers during the maturation divisions, fertilization, cleavage and development to the planula stage. The fully developed planula breaks out of the investments to take up a brief free-swimming existence prior to metamorphosis. Fertilization is internal, therefore, and the sperm must presumably negotiate the various cell layers surrounding the egg before fertilization can occur.

The structure of the gonangia of the two sexes of C. calceolifera (Fig. 6C,D) is much the same as that of $C$. flexuosa with two noteworthy exceptions in the case of the female. As can be seen in Figure $6 \mathrm{C}$, the distal end of the mature C. calceolifera female is elaborated into a hood-like structure protecting the small distal aperture. The hood results from an interaction between the cap ectoderm and the perisarc being laid down by the cap during maturation of the gonangium (Fig. 10). In this case, as in the maturation of the female gonangium of $C$. flexuosa, the form of the perisarc represents a frozen result of the activities of the underlying ectoderm. The second exception is in the manner of sequestering the eggs during fertilization. It appears from time-lapse films taken of maturation, that the egg in C. calceolifera is "ovulated" from the sporosac, but remains within the gonangium. Since we have not prepared sections of $C$. calceolifera female gonangia at this stage, it is not clear if the egg is still surrounded by one or more cell layers after "ovulation", though it does not alter position further within the funnel cavity of the gonangium. Nothing like this has been seen in the more extensively studied C. flexuosa. "Ovulation", followed by ex- 
trusion of the ripe ova from the gonangium, is the normal situation in C. gelatinosa, with fertilization taking place after egg release (MILLER, unpublished).

Maturation in both $C$. calceolifera and C. flexuosa results in the opening of the contents of the gonangium to the external environment, permitting the penetration of sperm into the gonangium. C. flexuosa has been most extensively studied with regard both to maturation in the female and sperm penetration to the egg (MILLER, 1969, unpublished; O'RAND 1972a, unpublished). Figure 9 represents a diagram of the process of maturation of the female gonangium of $C$. flexuosa. Stages of this process in C. calceolifera are shown in Fig. 10. Just prior to maturation in C. flexuosa growth in length ceases. Shortly thereafter, changes occur in the blastostyle cap, which result in its transformation from a nail-head shape into an inverted funnel with a wide opening at its distal end. This process has been divided into stages (see Fig. 9):

1. Proximal spreading $I$ : Proximal spreading of the epidermal cells on the lower edge of the cap accompanying or following cessation of growth in length. (Fig. 9A).

2. Groove: Formation of a circumferential groove around the blastostyle cap,
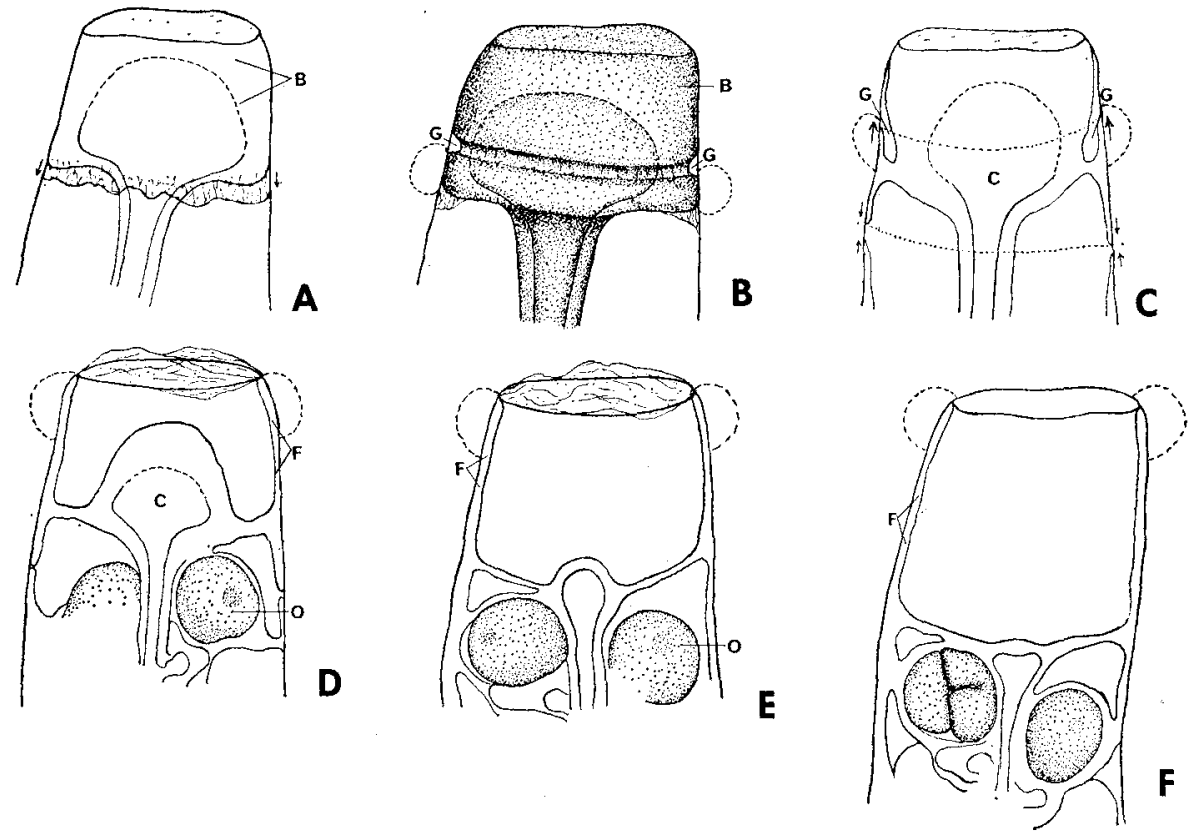

Fig. 9. Diagrammatic representation of stages of blastostyle cap morphogenesis during the maturation of the female gonangium of Campanularia flexuosa. See text for a detailed description of the figure. The small arrows represent the probable direction of movement of the epithelial cell sheets and the dotted lines within the gonotheca represent the edges of these cell sheets in part $\mathrm{C}$. The dotted lines outside the gonotheca represent the zone of sperm aggregation in each stage. Key: B, blastostyle cap; $\mathrm{C}$, gastrovascular cavity; F, funnel; $\mathrm{G}$, groove just forming; $\mathrm{G}^{\prime}$, groove at a later stage; $\mathrm{O}$, egg; $\mathrm{P}$, perisarc or gonotheca ; $\mathbf{P}^{\prime}$, perisarc cap sealing gonangium aperture. 


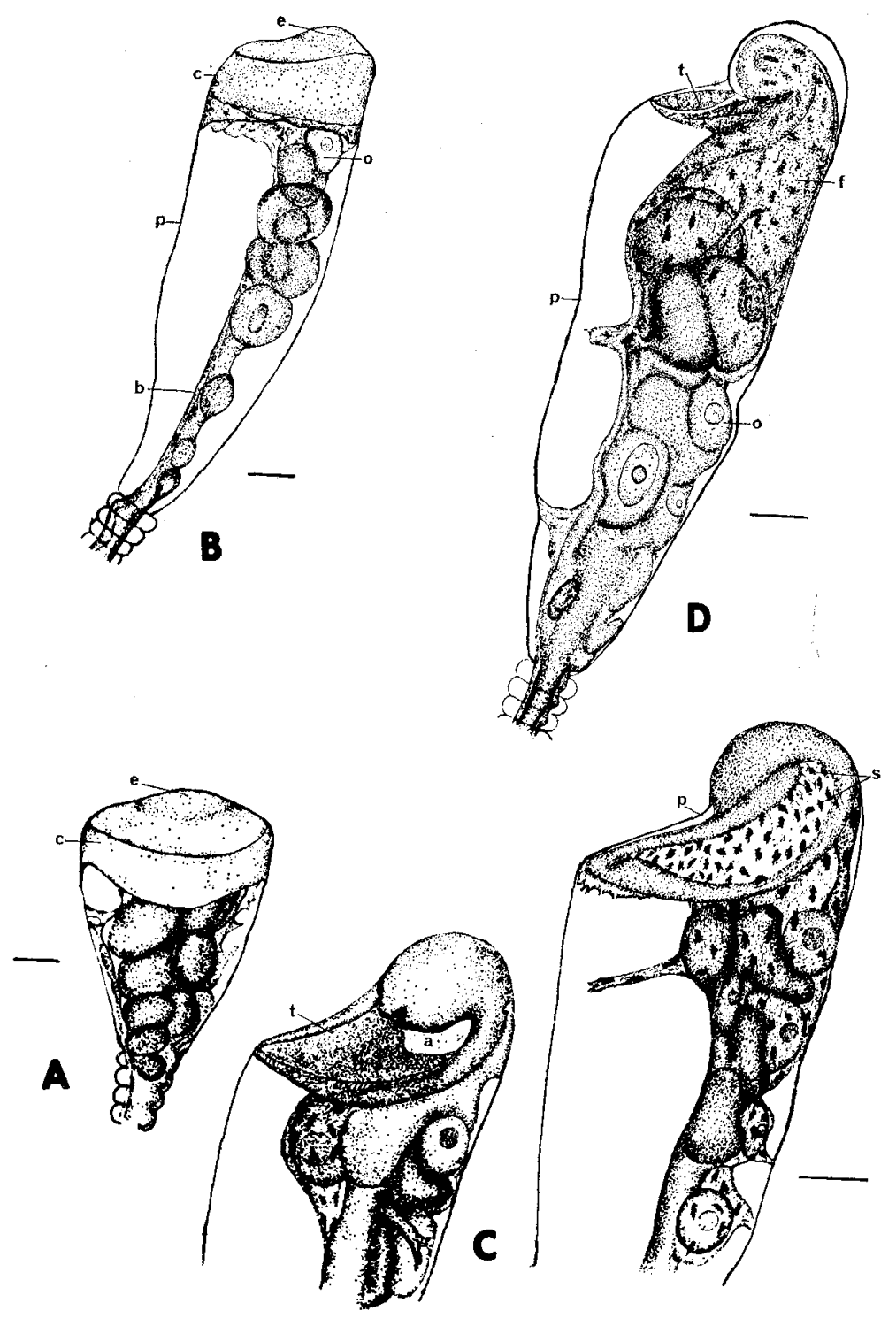

Fig. 10. Four stages during maturation of the female gonangium of Campanularia calceolifera. A. Young stage with oocytes not yet visible. Note the thick blastostyle cap with a swelling on one side. B. A much later stage, after the gonangium has elongated considerably. The ectoderm at the proximal edge of the cap has begun to spread downward on the inner surface of the gonotheca. The oldest oocyte is visible just under the cap. The bulge at one side of the cap is still prominent. C. Two stages of continued proximal spreading of the cap ectoderm accompanied by growth upwards of the cap bulge which loops inward to form the aperture. The black masses in the ectoderm sheets are the "secretory" cells prominent in the ectoderm of thecate hydroids. D. A mature female gonangium, showing the cap shelf forward of and under the aperture, and the large funnel cavity created by the ectoderm sheet. The two most distal oocytes protrude into this cavity. Key: a, aperture; b, blastostyle; $c$, blastostyle cap; e, bulge in the blastostyle cap; f, funnel cell epithelial layer; o, egg or oocyte; $p$, perisarc or gonotheca; $s$, secretory cells of ectoderm; $t$, cap shelf in front of aperture. The scale marks all represent $0.1 \mathrm{~mm}$. 
usually at some level on the sides of the cap. The groove deepens rapidly in a proximal direction, separating the bulk of the cap from the perisarc. Portions of the cap below the groove may be attractive to sperm at this time. (Fig. 9B,C).

3. Distal spreading: Movement of the ectoderm on the outside of the groove distally to the top of the gonotheca. This forms the upper wall of the funnel tissue. (Fig. 9C).

4. Blastostyle retraction: Pulling of the blastostyle cap away from the distal perisarc (the groove separates the cap from the lateral perisarc of the gonotheca), accompanied by rapid shrinking of the size of the cap. The distal perisarc remains in place, sealing off the inner cavity of the gonangium from the outside. (Fig. 9D,E).

5. Proximal spreading $I I$ : Marked spreading of the proximal "funnel" ectoderm cells to below the level of the distal-most sporosacs. (Fig. 9C,D).

6. Aperture formation: Fracture of the distal perisarc layer which opens the contents of the funnel chamber to the outside and permits sperm entry. Complete loss of the perisarc sheet soon follows. (Fig. 9E,F).

No such staging has been determined yet for the female gonangium of C. calceolifera since there seem to be fewer separable events visible during maturation in this species. The important events in C. flexuosa for this discussion are:

a. Movement of the sperm attracting cells distally to the tip of the gonangium.

b. Opening of the gonangium to permit sperm entry.

c. Formation of a channel (the "funnel") guiding the sperm toward the eggs.

d. Proximal spreading of ectoderm from the cap and blastostyle.

Chemotaxis of sperm to the tissue surrounding the aperture of the female gonan-

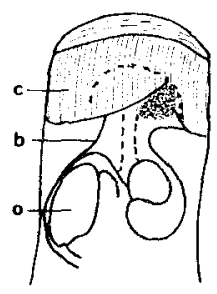

A

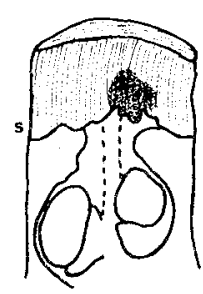

B

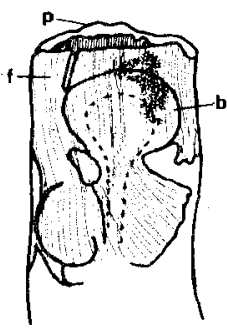

C
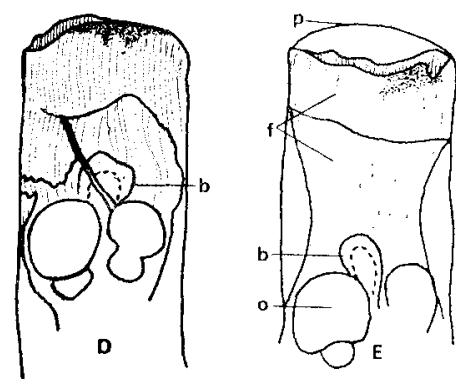

Fig. 11. Camera lucida drawings of the movement of a spot of Nile Blue Sulfate placed on the immature cap of a female gonangium of Campanularia flexuosa as maturation takes place. A. (0 hour) Immature cap, with dye placed at the lower edge of the cap (stippled area). B. (10 hours) Proximal spreading I stage, with the dye moving upward slightly. C. (23 hours) Groove formation and blastostyle retraction. The dye has shifted even further distally. D. ( 35 hours) Blastostyle almost fully retracted (Proximal spreading II) with all dye at the upper rim of the funnel. E. (45 hours) Mature female with funnel fully formed but perisarc seal still intact. Key: $b$, blastostyle; c, blastostyle cap; $f$, funnel tissue; $o$, egg or oocyte; $p$, perisarc seal over the gonangium aperture; s, spreading proximal ectoderm of the blastostyle cap (Proximal spreading I). 
gium of both $C$. flexuosa and C. calceolifera has been described in deiail by MiLLER (1966). As is suggested by the movements of blastostyle cap cells marked with Nile Blue Sulfate (Fig. 11), the cells most immediately involved in production of the sperm attractant have their origin below the position of the groove which appears around the cap edges early in maturation. The sperm aggregation which forms in response

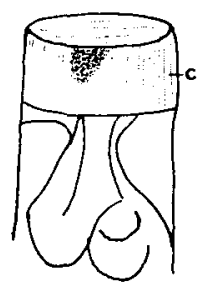

A

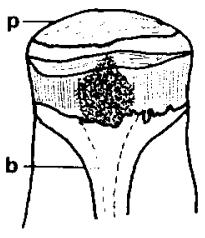

B

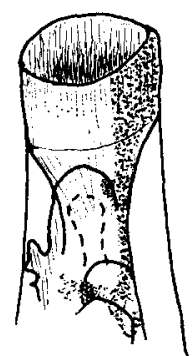

c

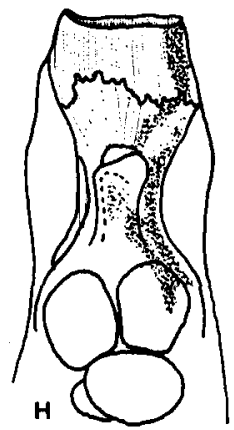

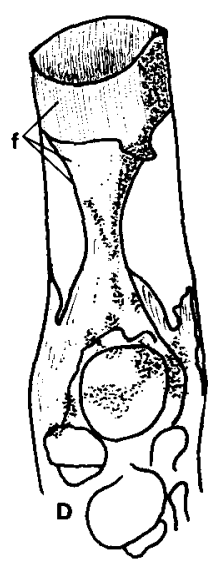

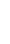

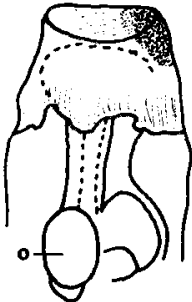

E

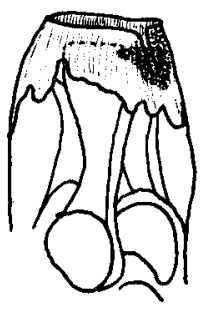

F

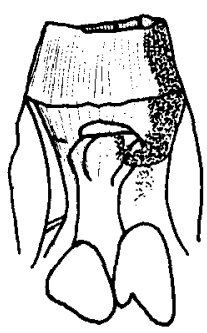

G

Fig. 12. Camera lucida drawings of the movements of a spot of Nile Blue Sulfate placed on the immature caps of two female gonangia (A-D and E-H) of Campanularia flexuosa as maturation takes place. In contrast to Fig. 11, the spots are placed at the upper edge of the caps. A,E. (0 hour); immature cap with dye spots (indicated by stippled zones) placed at the upper edge of the cap. B,F (11 and 12 hours, respectively); dye beginning to spread downward, having already reached the bottom of the cap edge in $\mathbf{B}$. In F, the dye is both on the epithelium outside the groove and on the blastostyle. C,G. (19 and 21 hours, respectively); the dye in $\mathrm{C}$ has spread well below the level of the still retracting blastostyle, to a position around the most-distal oocyte. D,H (34 and 39 hours, respectively); the blastostyle in $\mathrm{D}$ is fully retracted, while that in $\mathrm{H}$ is still apparent. Note that in both cases the dye has spread down over the most distal oocytes, the most striking case being E, where it has reached the second most distal oocytes. Key: b, blastostyle; c, immature cap; $\mathbf{f}$, funnel; o, egg or oocyte; p, perisarc or gonotheca. 
to the secretion of these cells is doughnut shaped, straddling the rim of the aperture. Many sperm are able to enter the gonangium once the perisarc seal, left in place by the retracting blastostyle cap, has broken. Sperm entering the funnel may swim freely within the chamber directly to the basal portions, or, more likely, they will strike the inner wall of the funnel before reaching the base. Usually, they stick to the funnel cells, mostly by their tails, but some movement is still possible, since the stickiness is weak enough that vigorous flagellar movements may break the sperm free of the epithelial cell surfaces (O'RAND, 1972a). Sperm observed within the female gonangium of $C$. flexuosa move in short bursts of activity, between which they remain quiescent and appear, by electron microscopy, to be attached to the epithelial cell surface by a homogeneous electron dense matrix (Fig. 13) (O'RAND, 1972a). Although there is no firm evidence of a chemical orientation mechanism guiding the sperm downward into the gonangium, attraction of the sperm to the retracted blastostyle tip has been demonstrated in a few cases by O'RAND (personal communication). This might account for sperm aggregations seen in the lower part of the funnel under optimal conditions (MILLER, unpublished) although most of the sperm could have reached this area by chance. Once the sperm have reached the base of the funnel, however, it appears that they must pass through a minimum of two cell layers to reach the surface of the egg in C. flexuosa, one being the cell sheet composing the funnel itself, the other being the thin epithelial layer surrounding the egg. In $C$. calceolifera, the ovulation process may reduce this by one layer, since the egg appears to be shoved up into the funnel cavity proper.

The passage of spermatozoa beyond the funnel cavity has been described by O'RAND $(1972 \mathrm{a}, \mathrm{c})$. Their passage is evidently partly dependent on the development of blind and complete passageways within the proximal funnel zone leading from the edge of the funnel cavity down toward the gonomedusae bearing ripening oocytes. The formation of the channels probably depends on the final stages of gonangium maturation, particularly stage 5, proximal spreading II. At this time, the basal part of the cell sheet which forms the funnel penetrates well down into the proximal portions of the gonangium, below the level of the distal-most set of eggs. Figure 12 shows two examples of this revealed by vital staining of the ectoderm cells of the lower part of the blastostyle cap. Presumably, the invading cell sheet and the ectoderm layer surrounding the oocytes unite (Fig. 14a) to form channels, at least some of which pass close to the germinal vesicle area of the eggs. One example of this is shown in Fig. 14, where a channel has been traced over 300 microns from the base of the funnel to the surface indentation of the germinal vesicle of an oocyte lying below the distal-most set of gonomedusae in the gonangium. O'RAND $(1972 \mathrm{a}, \mathrm{c})$ has shown that these channels run both proximally and laterally in the gonangium, that they branch, and that contain sperm almost as soon as the perisarc seal over the aperture has broken.

O'RAND (1972a) has also shown that important alterations in the capacity for fertilization and the morphology of the sperm occur during sperm penetration into the 


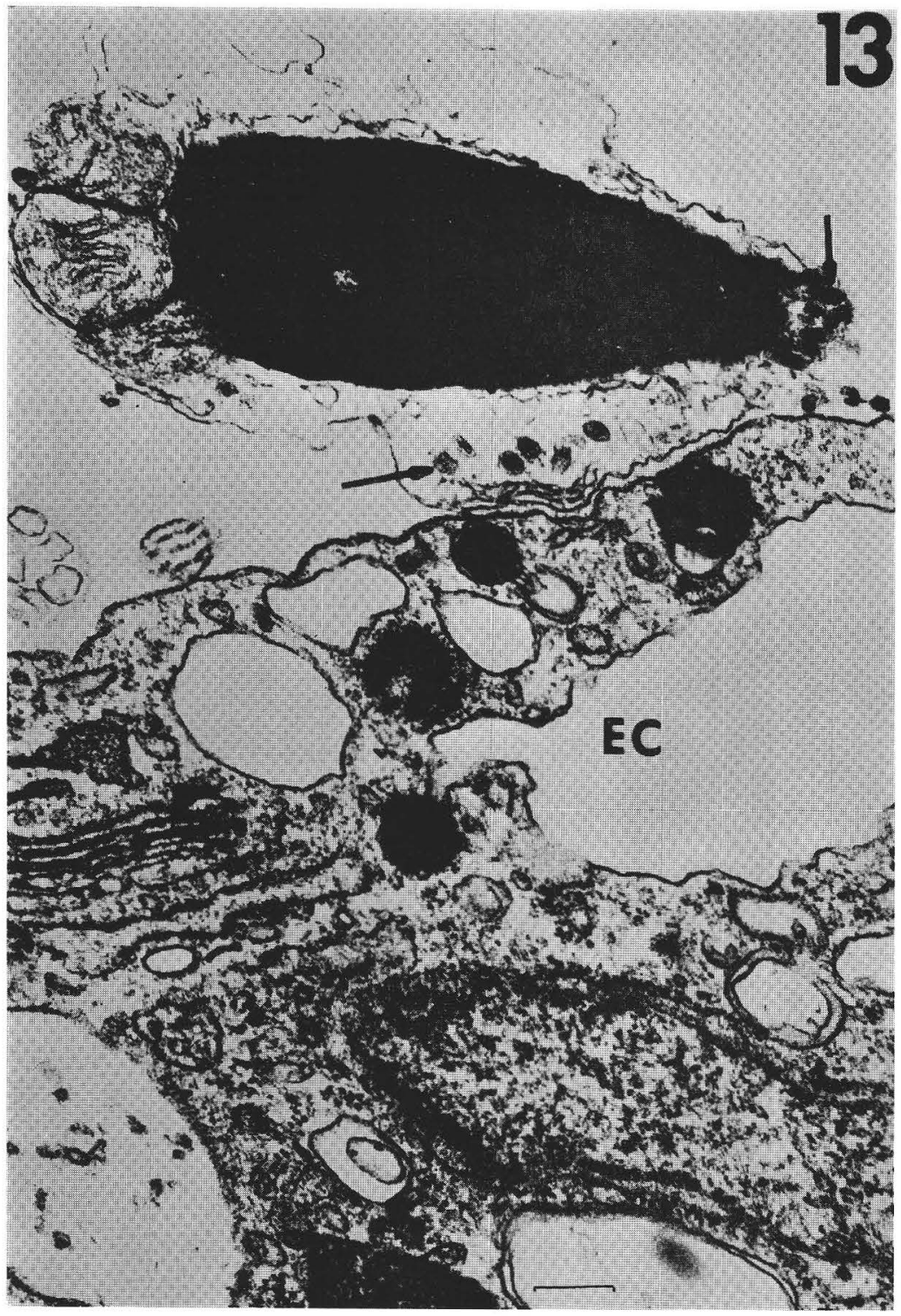

Fig. 13. Electron micrograph of a Campanularia flexuosa spermatozoon adhering to a funnel epithelial cell (EC) of the mature female gonangium. Note the apical and lateral membrane-bounded vesicles (arrows) and the electron-dense material between the sperm and epithelial cell plasma membranes. Scale represents 0.1 micron. (From O'RAND, 1972a). 

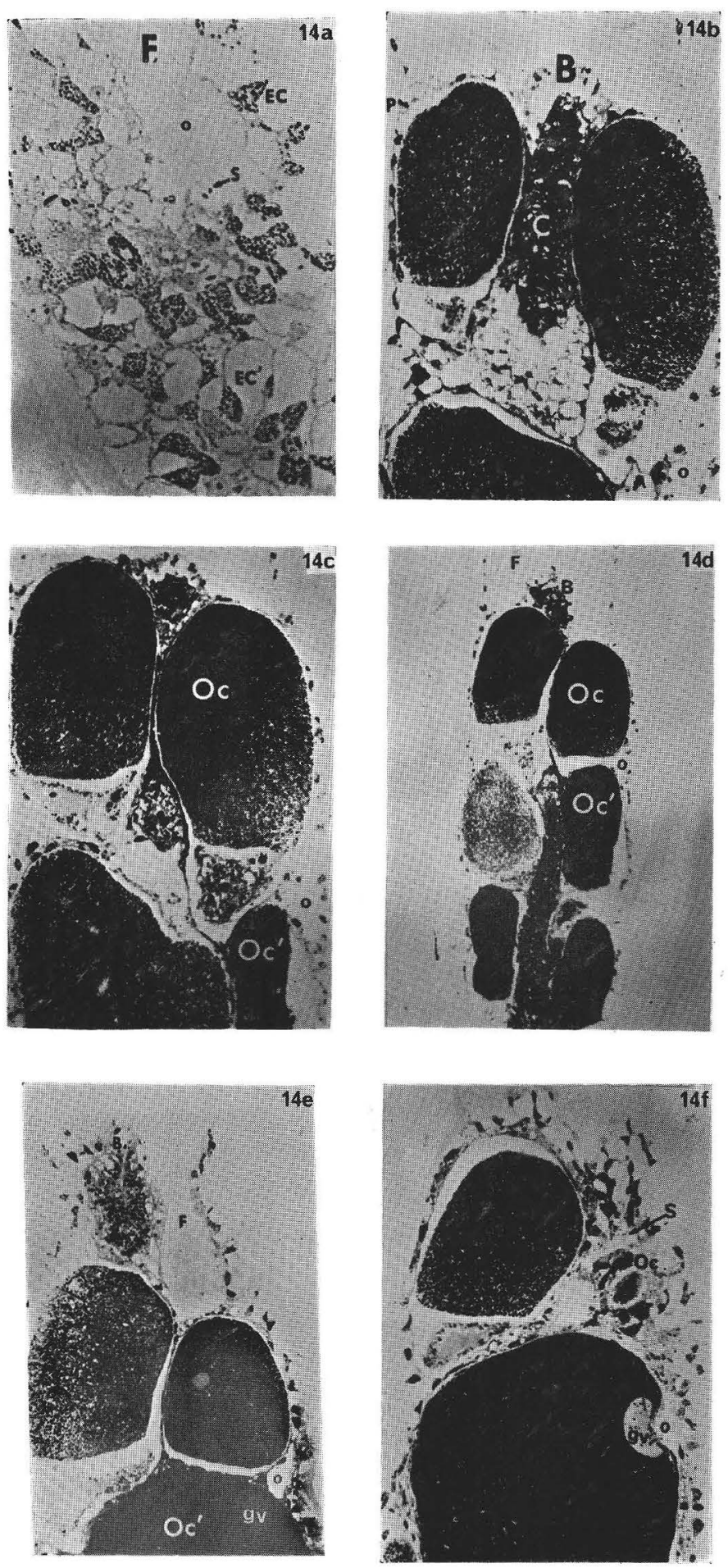


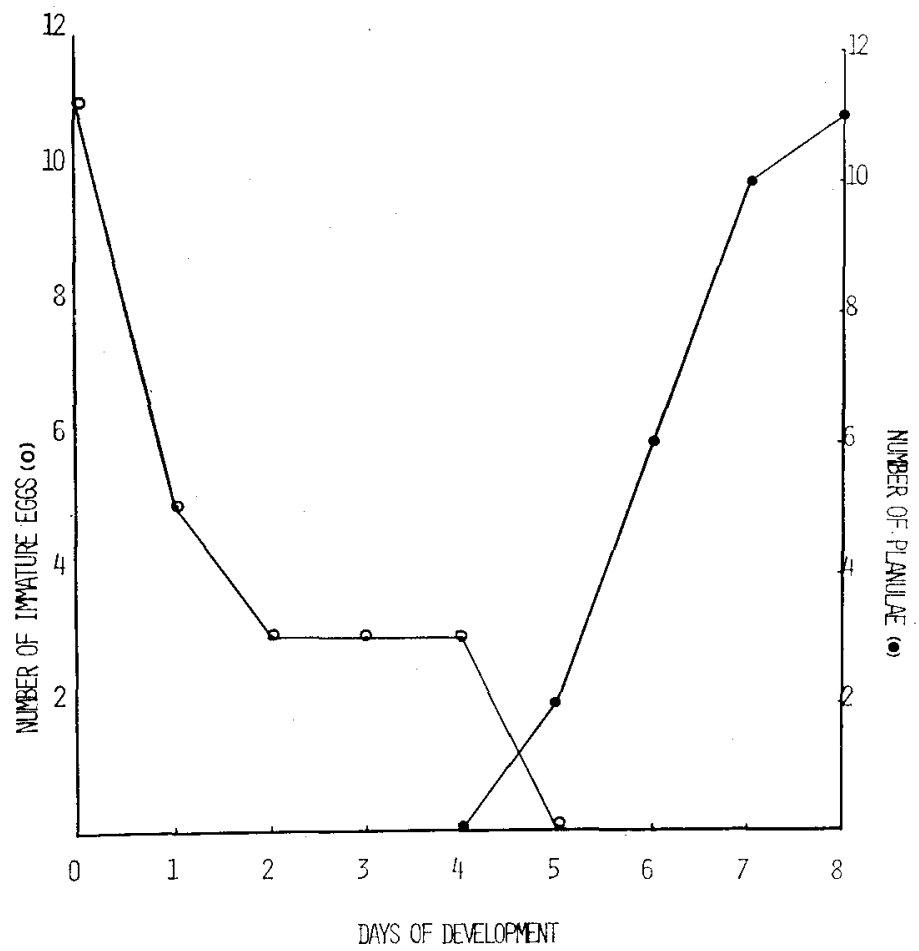

Fig. 15. In vitro loss of immature eggs (०) and development of planulae (•) in egg packets taken from freshly collected colonies of Campanularia flexuosa. Sperm were not added to this preparation. The packets were incubated in millipore filtered sea water at $12^{\circ} \mathrm{C}, \mathrm{pH} 7.8$. (From O'RAND, 1972a, c).

Fig. 14. Light micrographs of serial sections of a mature female gonangium of Campanularia flexuosa illustrating one passageway which leads from the funnel cavity to the germinal vesicle of an egg. a. Peripheral longitudinal section showing part of the funnel cavity (F) and the funnel epithelial cells (EC) which are confluent with the epithelial cells (EC') which surround the oocytes. Sperm (S) are in the funnel cavity which may be followed transversely as a passageway $(0) . \times 635$. b. The passageway $(0)$ from the funnel cavity has been traced below the most distal oocyte. (B, blastostyle; C, coelenteron; $\mathrm{P}$, perisarc). $\times 228$. c. As the longitudinal plane of section moves through the gonangium, the passageway (o) becomes situated between the most distally located oocyte (Oc) and the next most proximally located oocyte $\left(\mathrm{Oc}^{\prime}\right) . \times 197$. $\mathrm{d}$. A medial longitudinal section showing the blastostyle (B) located at the proximal end of the funnel cavity (F). The passageway (o) is still located on the right side between (Oc) and $\left(\mathrm{Oc}^{\prime}\right)$. $\times 101$. e. The passageway $(\mathrm{o})$ continues above $\left(\mathrm{Oc}^{\prime}\right)$ as more of the gonangium is cut, and the germinal vesicle $(\mathrm{gv})$ of the oocyte $\left(\mathrm{Oc}^{\prime}\right)$ can now be seen. $\times 194$. f. The germinal vesicle $(\mathrm{gv})$ of $\left(\mathrm{Oc}^{\prime}\right)$ is crescent shaped and is adjacent to an indentation in the oocyte surface. Note the closely adherent epithelial cells which completely surround the oocyte. Sperm (S) may be seen in another passageway above the remains of the most distal oocyte (Oc). (Entire figure from O'RAND, 1972a). 


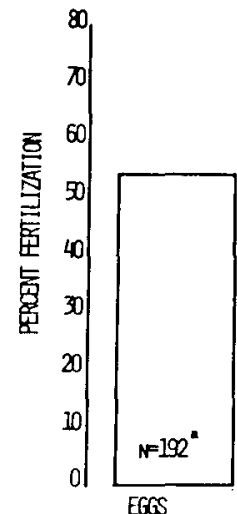

A

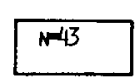

EGGS +

TRYPSIN

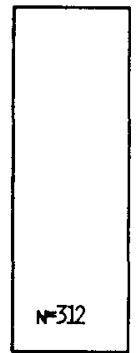

EGES + SPERM

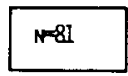

EGGS +

TRYPSIN +

SPEM

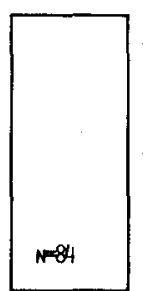

EGOS + TRYPSIN + BPI. CELLS + SPEPN

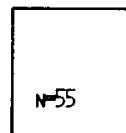

EGOS + EPI. CEUSS + TRYPSIN + SPEPA

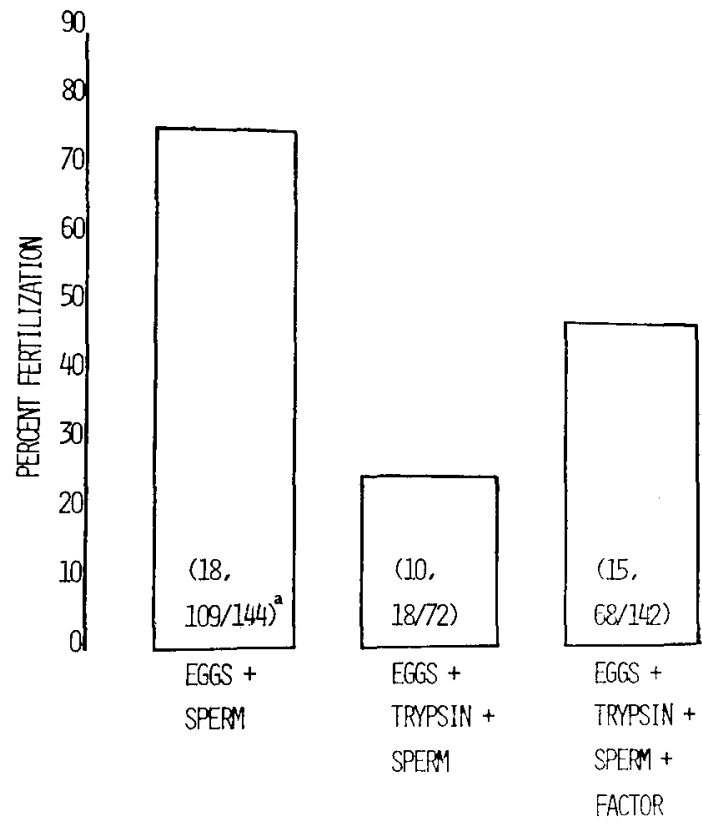

Fig. 16. A. In vitro fertilization after $0.75 \%$ trypsin treatment of egg packets from gonangia of freshly collected colonies of Campanularia flexuosa by spermatozoa exposed to trypsin treated and untreated female gonangium funnel epithelial cells. $a=$ total number of unfertilized eggs in egg packets. $b=0.75 \%$ trypsin for one hour at $20^{\circ} \mathrm{C}, \mathrm{pH} 7.8 . \quad \mathrm{c}=$ female gonangium funnel epithelial cells not treated with trypsin. $d=$ female gonangium funnel epithelial cells treated with trypsin. (From O'RAND, 1972a,c).

B. In vitro fertilization of $C$. flexuosa eggs in egg packets treated with $0.75 \%$ trypsin (one hour, $20^{\circ} \mathrm{C}, \mathrm{pH} 7.8$ ). After washing five times in millipore-filtered sea water, the packets were exposed to sperm in the presence or absence of the soluble fertilization enhancing factor. $\mathrm{a}=$ (individuals; fertilized eggs/total number of eggs). (From O'RAND, 1972a, d). 
female gonangium of C. flexuosa. The fertilizing capacity of the sperm is markedly reduced if they are not allowed to come into contact with normal female epithelial cells (O'RAND, 1971, 1972a). This has been demonstrated by treating egg packets (composed of the proximal egg mass enclosed by the lower funnel epithelial cells) which have been squeezed out of the gonotheca with a weak concentration of trypsin $(0.75 \%)$ in sea water for one hour at pH 7.5 (O'RAND, 1971, 1972a). After the trypsin has been washed out, it is found that the addition of normal sperm to the packets results in considerably lower rates of fertilization with respect to the controls (Fig. 16A). Calcium-magnesium-free sea water and pronase have similar effects, but appear to damage the eggs, such that their ability to be fertilized is permanently damaged. The fertilization rate of treated packets can be brought back to that of the controls by exposing the sperm to female epithelial cells which have not been trypsin treated (Fig. $16 \mathrm{~A}$ ), or by adding a cell-free wash of calcium-magnesium-free sea water treated egg packets (O'RAND, 1972a,b) to the medium in which the trypsin-treated packet is to be exposed to sperm (Fig. 16B). The cell-free wash has been called a fertilizationenhancing factor (O'RAND, 1972a).

Over-all life span of the sperm is probably affected by association with the female gonangium. On the microscope stage, the sperm of Tubularia are motile for 10-20 minutes, those of Campanularia for 30-45 minutes, and those of Clava for even longer. Addition of sperm attractants extracted from the females of these species enhances motility even at the ends of these times, providing evidence that the secretions of the female gonangium are beneficial to sperm. That this is the case is demonstrated even more dramatically by observations of O'RAND (1972c) on the time of fertilization of eggs in two gonangia removed from the presence of males after performation of the perisarc cap and when several large oocytes still remained in the proximal portion of the gonangium (Fig. 15). Since the last oocyte disappears on day 4, and all oocytes eventually developed into larvae, it seems that sperm can survive and fertilize eggs after a residence of four days in the female gonangium.

It appears, therefore, that sperm contact with a protease-sensitive component produced by the female gonangium epithelial cells is required for fertilization to take place, and may entend the fertilizable life of the sperm. The exact nature of this component is unknown, though evidence at the ultrastructural level indicates that it is a surface component of the epithelium (O'RAND, 1972a,c). Circumstantial evidence suggests that one of the effects of the fertilizing enhancing factor on the sperm occurs below the surface membrane, since O'RAND has shown that the sperm of C. flexuosa display reduction of the number of "pro-acrosomal" vesicles the deeper they have penetrated into the female gonangium and, presumably, the longer they have remained in contact with the gonangium epithelial cells (Table 1) (O'RAND et al., 1973). The loss of vesicles appears to be species-specific, since Gonothyrea or Clava sperm do not show vesicle loss within C. flexuosa female gonangia (O'RAND, 1972a). However, vesicle loss has not been investigated for the sperm of these two species when they are 
Table 1. Spermatozoan vesicle loss during penetration of the female.

\begin{tabular}{|c|c|c|c|c|c|c|c|}
\hline & $\begin{array}{l}\text { No. of } \\
\text { sperm }\end{array}$ & $\begin{array}{l}\text { No. of } \\
\text { vesicles }\end{array}$ & $\begin{array}{l}\text { Total } \\
\text { vesicles } \\
\text { per sperm* }\end{array}$ & $\begin{array}{l}\text { Vesicles/ } \\
\text { sperm/ } \\
\text { section }\end{array}$ & s.d. & $t_{\infty}$ & $\mathrm{p}$ \\
\hline C. flexuosa sperm & 135 & 687 & 73 & 5.1 & 3.4 & 1.38 & $<.1$ \\
\hline $\begin{array}{l}\text { C. flexuosa sperm in } \\
\text { female funnel }\end{array}$ & 20 & 80 & 58 & 4.0 & 2.3 & 2.29 & $<.025$ \\
\hline $\begin{array}{l}\text { C. flexuosa sperm in } \\
\text { female channels }\end{array}$ & 117 & 278 & 35 & 2.4 & 2.6 & & \\
\hline $\begin{array}{l}\text { C. flexuosa sperm at } \\
\text { egg surface }\end{array}$ & 5 & 3 & 8.6 & 0.6 & 0.5 & 1.48 & $<.1$ \\
\hline
\end{tabular}

* Calculated from average observed volume of sperm. (From O'RAND et al., 1973).

in contact with the homospecific female gonomedusa.

\section{Discussion}

Four descriptions of gonomedusa and gonangia structure and function have been presented in this paper. Besides demonstrating considerable gaps in our knowledge of the accurate developmental anatomy of these structures, the descriptions serve to point up the remarkably sophisticated fertilization physiology possessed by many hydroids, and the close connection between the development of the reproductive structures and the timing of both the penetration of sperm into the reproductive structure and the maturation of the eggs. The descriptions proceed from a structurally simple gonomedusa (the acrocyst of Cordylophora) to a complex reproductive polyp with multiple internal gonomedusae (the gonangium of Campanularia). The ordering is intended to demonstrate the addition of new specializations for sperm manipulation prior to fertilization as the female reproductive structures increase in complexity. In summary, the gonomedusa of Tubularia restricts sperm entry to an apical opening that is a remnant of the medusa bell opening, and produces a sperm attractant to induce sperm aggregations around this opening. This may be contrasted to Cordylophora, where no such opening exists, and where there appears to be no evidence for sperm attraction or physical constraints orienting sperm movements. The female meconidium of Gonothyrea, structurally similar to the gonomed usa of Tubularia, also produces a sperm attractant near the base of the apical tentacles. The species-specific adherence to and sperm migration along the meconidium tentacles described by MiLLER (1970) has apparently been added on to a situation basically like that of Tubularia. The tentacle adherence serves as a significant constraint on sperm behavior and motility, acting to guide the sperm in the vicinity of the female meconidium aperture. It is not 
yet known if the migrating sperm also respond to the attractant gradient while moving on the tentacles.

In Campanularia, a chemoattractant is produced by epithelial cells of the female gonangium that are derived from a zone homologous with the tentacular zone of the polyp. These cells are also sperm sticky and may be considered analogous to the female meconidium tentacles of Gonothyrea in function. A new addition is the development of special epithelial channels, formed as a result of the epithelial movements during gonangium maturation, that lead directly to the eggs. These channels could be considered morphological inversions of the tentacle surface pattern of the female meconidium of Gonothyrea. It seems clear from the diameter of the channels $(5-30 \mathrm{mu})$ in relation to the length of the sperm flagellum $(40-50 \mathrm{mu})$ that the channels act as significant constraints on the direction of movement of the sperm, since the sperm would have some difficulty reversing direction in the narrowest portions of the channels. A further constraint on sperm motility, also similar to one found in Gonothyrea, arises from the stickiness of Campanularia sperm to the epithelial cells which compose the walls of the channels (Fig. 13); a stickiness which has already been found to occur at the level of the funnel epithelial cells (O'RAND, 1972a). Whether any further constraints on direction of sperm movements occur once they have penetrated deep into the gonangium, such as a secondary chemo-attraction to the germinal vesicle of the egg, remains to be determined. The possibility of such an attraction is supported by the observations of sperm aggregations close to the germinal vesicle of the egg in Spirocodon, Hydra and Cyanea made by DAN (1950), BRIEN (1965) and WIDERSTEN (1965) respectively, using mainly fixed material. Since the behavior of the living sperm was not reported, MILLER's definition of chemotaxis as related to sperm behavior (1972a) cannot be applied to any of these situations.

The suppressed sperm flagellar movements observed during sperm penetration of the acrocyst wall described here for Cordylophora occur also during sperm migration on the female meconidium tentacles of Gonothyrea. Similar movements, interspersed with bursts of active swimming occur as Campanularia flexuosa sperm move into the epithelial channels within the female gonangium. The basis for the suppression of flagellar activity in all of these cases is unknown but the wave morphology resembles that observed by BROKAw (1966) in Ciona and Lytechinus sperm swimming in a high viscosity medium (greater than $40 \mathrm{Cp}$ ). The mechanism of penetration of Cordylophora sperm through the acrocyst wall also remains to be determined. It is probably the same for all hydroids producing acrocysts and may be related to the release of acrosomal enzymes which are known in other sperm to be capable of dissolving egg jellies (TYLER, 1949; TYLER and TYLER, 1966). One might ask if sperm boring behavior occurs in genera like Clava, where the mature female gonomedusa outer wall is, in part, composed of a thick mesogloea-like layer. Preliminary observations of sperm approach and penetration in Clava indicate that a general attraction of sperm to the entire surface of the female gonomedusa occurs but no evidence of any specializations 
for sperm entry into the gonomedusa could be seen using the light microscope, nor were sperm seen to bore into the gonomedusa wall.

WEISMANN (1883) commented on a similar problem in the hydroid Eudendrium, suggesting two mechanisms for the penetration of sperm into the female gonomedusa. One of these is penetration of the sperm through the thin outer ectoderm epithelium of the gonomedusa. He also reported observing a small opening at the apex of the female blastostyle of Eudendrium capillare and supposed that the sperm could enter the gastrovascular cavity of the blastostyle and approach the eggs from within the coelenteron. Since he saw the opening only once, despite study of thousands of sections, he assumed that it appears only when an egg is ripe or when sperm are present in the sea water surrounding the female blastostyle. If the latter is the case, then some kind of sperm receptors must be present on the blastostyle and WEISMANN suggests that the apical tentacles might serve in this capacity. These tentacles lack nematocysts, are absent in the male, and degenerate once all the eggs borne by the blastostyle have been fertilized. MERGNER (1957) accepts the temporary opening hypothesis, particularly in view of his observations that the egg nucleus comes to rest close to the endoderm layer of the blastostyle when the egg is mature. The path of the sperm penetrating to the egg suggested by MERGNER (1957) after Weismann (1883) is, in fact, remarkably similar to the actually observed movements of sperm toward the eggs in Gonothyrea loveni (Miller, 1970). However, once sperm have entered the gastrovascular cavity, they must still penetrate the endoderm and mesogloea to reach the egg, which creates a problem at least equivalent to that posed by sperm penetration of the outer ectoderm layer of the gonomedusa. Summers (1972) claims that a micropyle-like opening exists in the ectoderm layer surrounding the egg in Eudendrium but does not present any observations of sperm behavior in the vicinity of the female gonomedusa. In view of the work reported here in other species, penetration into the gonomedusa through the outer ectoderm wall, whether through a micropyle or not, seems quite probable.

There appears to be circumstantial evidence for the penetration of cell layers surrounding the eggs by sperm prior to fertilization in at least some of the hydroids discussed in this paper. It is known that the mature eggs of Tubularia, Gonothyrea, and Campanularia are enveloped by at least one closely adherent thin layer of epithelial cells (Van de Vyver, 1968; Benoit, 1925; Weismann, 1883; Allman, 1863; O’Rand, 1972a,c; Miller, unpublished). It is also possible that thin layers of ectoderm cells, invisible at the level of the light microscope, invest the inner and/or outer surfaces of acrocysts of some species. Such a layer is present on the outer surface of the Campanularia urceolata acrocyst in Fig. 17. How the sperm penetrate these layers is unknown but the "pro-acrosomal" vesicles may play a role. Alternatively, the cell layers may break down at the time of egg maturation as suggested by the observations of O'RAND (1972a) that the cells in the most closely adherent ectoderm layers surrounding the Campanularia flexuosa egg separate at the time of maturation. This 
might have been caused by sperm releasing "pro-acrosomal" enzymes in the vicinity of the egg, however, and may not be a direct result of egg maturation. Whether sperm penetration of or at least interaction with these layers or other portions of the gonomedusa is required for normal fertilization to occur in species other than $C$. flexuosa (O'RAND, 1972a,b) remains to be determined.

Species-specific chemotaxis of hydroid sperm to the female gonomedusa or gonangium has been described in some detail by Miller (1966, 1972a,b). The molecules responsible are polar, heat stable and of less than 700 molecular weight (MILLER, 1972b). At present, at least seven species of hydroids are known to be capable of attracting their own and often other species' sperm. Cross-generic attraction occurs, a particularly interesting case being that between Campanularia calceolifera and Gonothyrea loveni (Mrller, 1970, 1972b), but so far attempts at hydridization have not succeeded mainly for technical reasons. Whether this phenomenon (chemotaxis) can be extended to other species of hydroids requires much further work. The fact that Clava female gonomedusae attract sperm indicates that almost all hydroids with sessile gonomedusae probably attract their sperm chemically, since the Clava-type gonomedusa represents a common morphological type, and resembles an acrocyst when fully mature.

Species-specific "pro-acrosomal" vesicle release and sperm adherence to gonomedusa cell surfaces have been studied carefully only in Campanularia flexuosa (O'RAND, 1972a, O'RAND et al., 1973) where the former occurs progressively as the sperm move deeper into the female gonangium. It is known that species-specific sperm adherence to the tentacles of the female meconidium of Gonothyrea loveni occurs (Miller, 1970), and certainly the possibility exists in Cordylophora and other forms possessing acrocysts but they are, as yet unstudied. Sperm-acrocyst wall specificity should be more easily testable in Sertularia and Plumularia than in Cordylophora, since numerous species that possess this structure of something similar exist in these two thecate genera. It is not known, in Gonothyrea, if the "pro-acrosomal" vesicles are released during sperm attachment and migration on the tentacles of the female meconidium, nor is it known how they behave (even if they exist) during the penetration of the acrocyst wall in Cordylophora. What effect vesicle loss has on the locomotory abilities and fertilizing capacities of hydroid sperm is uncertain, particularly as it is not clear what relationship the "pro-acrosomal" vesicles (HINSCH and ClARK, 1970) bear to the highly developed egg-membrane penetration organelles (DAN, 1970) of the sperm of higher invertebrates. There is no evidence at present that the vesicles actually function during sperm penetration of the egg membrane itself, since gamete fusion has not been observed with the electron microscope for any coelenterate.

It is important to note that the organization of the gonomedusa structure at the acrocyst level is found in genera of hydroids considered to be more evolutionarily advanced than Cordylophora. The three species of Sertularia in Fig. 18 all possess complex gonothecae, but nevertheless two of the three extrude acrocysts bearing 
mature or already fertilized eggs. Acrocysts of a similar nature also occur in the species Campanularia urceolata (Fig. 17), even though the mature female gonangium resembles that of C.flexuosa in considerable detail. At least some members of the genus Plumularia possess acrocyst-like structures that are produced from the openings of Campanularia-like female gonangia. These consist of jelly streamers, which do not carry eggs or embryos but apparently act as sperm traps that may guide sperm, once they are in the jelly, down toward the eggs within the gonangium. It would be interesting to determine how sperm approach and penetration is regulated in these species particularly in view of the prefertilization events described in this paper for Cordylophora and Campanularia flexuosa. The effects of other somatic specializations, such as the complex blastostyle development in two of the species of Sertularia in Fig. 18,
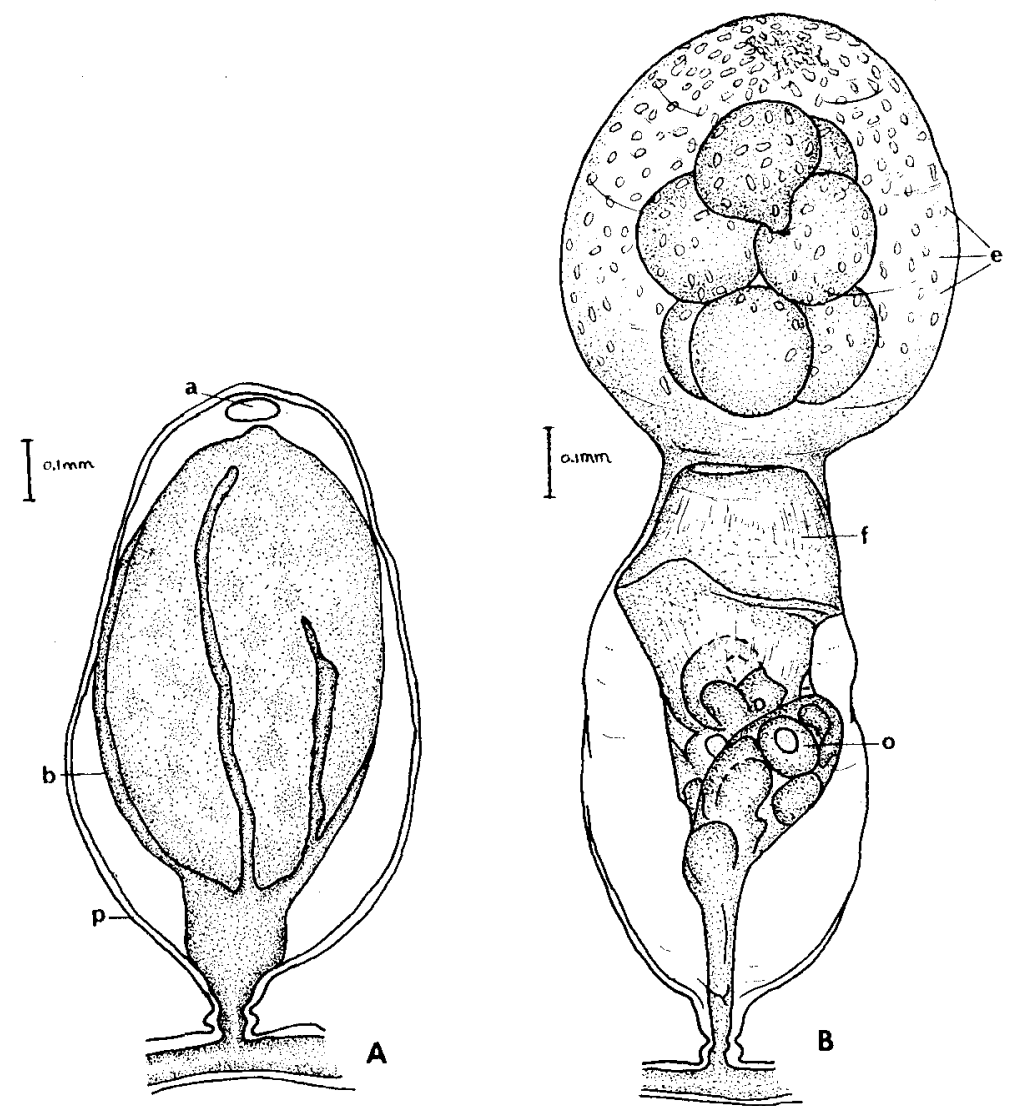

Fig. 17. Male (A) and female (B) gonangia of Campanularia urceolata. The female gonangium bears and acrocyst containing a cluster of ripe or fertilized eggs. Note, in the female, the funnel at the distal end of the gonangium proper and the small oval structures on the surface of the acrocyst which represent ectodermal secretory cells. Key: a, aperture of the male gonangium; $b$, blastostyle; e, acrocyst; $f$, funnel; $o$, eggs; $p$, perisarc. 
or the envelopment of clusters of gonangia by the branches of the colony which make up the corbula in Aglaophenia (Fig. 19) or the association of polyps with the gonangium as in Halecium, must also be considered. Although the corbulae of Aglaophenia pluma are sexually dimorphic (MILLER, unpublished), nothing is known concerning sperm approach and penetration into this structure in this species.

Internal fertilization in the hydroids has resulted in the development of a set of properties in the gonomedusa or gonomedusa-related somatic structures which aid sperm penetrating to the eggs. These structures, in the form of protective tissue or jelly layers serve as barriers to the sperm, possibly acting to prevent polyspermy, while the production of low molecular weight sperm attractants and the development and elaboration of gonomedusan and gonangial apertures and sperm guidance channels serve to enhance the chances of successful fertilization. Furthermore, surface related molecular constituents confer fertilizing capacity on penetrating sperm and possibly prolong the life-span of sperm inside the female reproductive structure (O'RAND, 1972a,c). They may also confer at least partial species-specificity on the fertilization process by effectively filtering out sperm of the wrong species. Elimination of undesirable sperm is evidently accomplished through phagocytosis by the gonangium epithelial cells in Campanularia (O'RAND, 1972a), and presumably some type of surface recognition mechanism exists in this species that mediates this reaction. The existence of a surface recognition mechanism for sperm identification based on adherence has
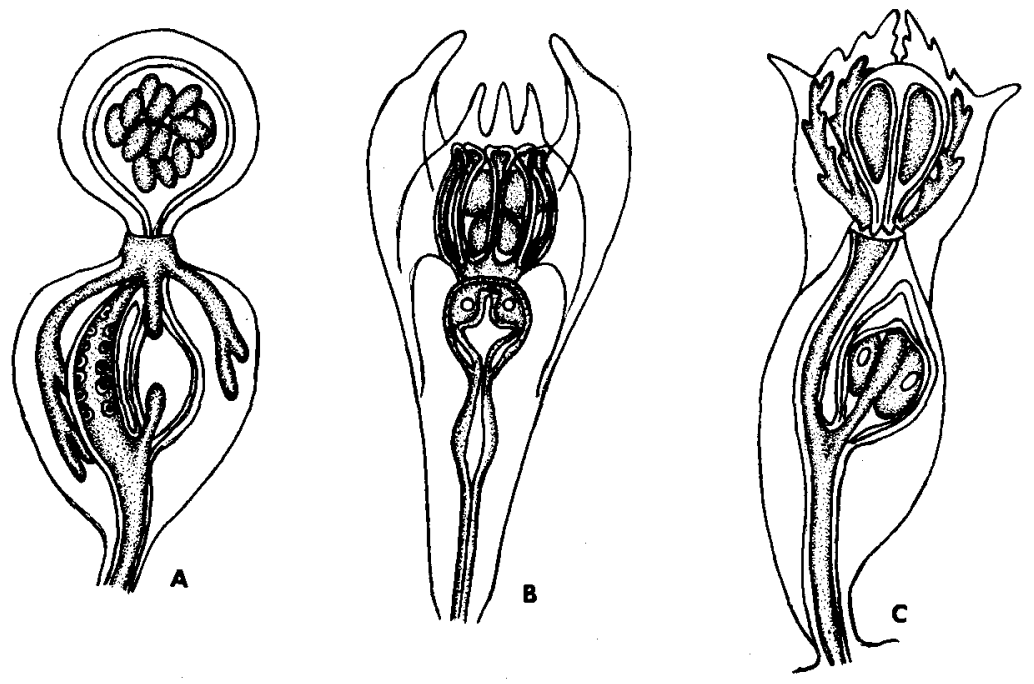

Fig. 18. Female gonangia of three species of Sertularia showing the structure of the perisarc, blastostyle and gonomedusae. A. Sertularia pumila. B. Sertularia rosacea. C. Sertularia tamarisca. Both A and C have extruded acrocysts while B has sequestered the eggs in a cup shaped elaboration of the blastostyle. (Redrawn from Allman, 1863). 


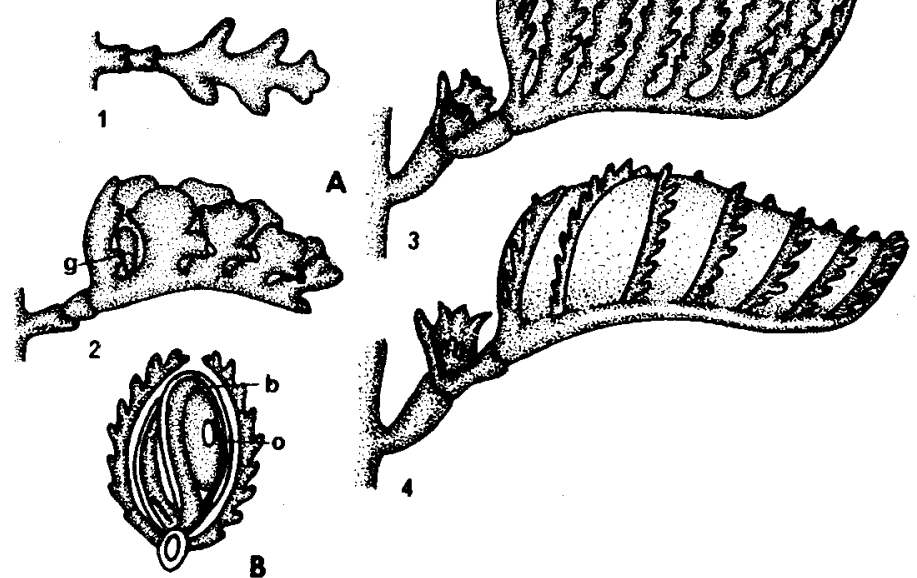

Fig. 19. A. Four stages (1-4) in the development of the corbula of Aglaophenia pluma. Stage 4 represents the completely sealed off corbula. B. Section through the corbula at approximately stage 3 , showing one complete gonangium and a portion of another. The gonangia are omitted from the stage 3 of part A. Key: b, blastostyle; g, developing gonangium; o, egg or oocyte. (Redrawn from Allman, 1863).

already been suggested for Gonothyrea (MILLER, 1970), though the specificity is not complete. Species-specific sperm exclusion mechanisms may also exist at the egg surface. Thus, a number of levels of specificity exist for the regulation of fertilization in Campanularia and the foregoing discussion suggests that other hydroids may regulate their fertility in similar ways. However, sperm penetration mechanisms have not been studied in enough species to permit any conclusions about the prevalence of the phenomena described in this paper within the entire order or the relevance of them for the population biology, evolution and ecology of the group.

With the exception of chemotactic attraction of sperm, all the prefertilization events described for hydroids in this paper resemble the prefertilization gamete interactions in a wide variety of other invertebrates with external fertilization (TYLER and TYLER, 1966), and also in many vertebrate systems, particularly amphibians (SHIVERS and JAMES, 1971; ELINSON, 1971) and mammals (see BEDFORD, 1972, for a review). It is likely that they exist in all cases where sperm are deposited or make their way into the female reproductive tract prior to fertilization. The fact that these mechanisms are so well developed in organisms of such simple construction and long evolutionary history as the Hydrozoa is an indication of their fundamental utility for fertilization regulation in animals. 


\begin{abstract}
Aknowledgements
The author wishes to thank the staffs of the following marine stations for their help while he was in residence: the Marine Biological Laboratory, Woods Hole, Mass.; the Kerckhoff Marine Laboratory, Corona del Mar, California; the Bodega Marine Station, Bodega Bay, California; the Marine Science Center, Newport, Oregon. Discussions with Dr. Michael O'Rand contributed materially to the ideas expressed in this paper. Portions of the work reported were supported by a post-doctoral fellowship (HD 19,931) from the USPHS, NIH, and grant HD-04543, from NIH, Child Health and Human Development.
\end{abstract}

\title{
REFERENCES
}

Allman, G. 1863. Report on the present state of our knowledge of the reproductive system of the hydroida. Report of the Thirty-third Meeting of the British Association for the Advancement of Science, pp. 351-426.

BEDFORD, J. M. 1972. Sperm transfer, capacitation and fertilization. In "Reproductive Biology" (H. Balin and S. Glasser, eds.). Exerpta Medica Monograph. Amsterdam.

Benoit, P. 1925. L'ovogénèse et les premiers stades du développement chez la Myriothele et chez la Tubulaire. Arch. Zool. Exp. et Gén., 64: 89-326.

BrIEN, P. 1965 L'embryogénèse et la sénescence de 1'Hydre d'eau douce Hydra fusca (oligactis) PALLAS. Acad. Roy. de Belgique, Classe d. Sci. Mém. Collection. 36: 1-113.

BrokAw, C. J. 1966. Effects of increased viscosity on the movements of some invertebrate spermatozoa. J. Exptl. Biol., 45: 113-139.

DAN, J. C. 1950. Fertilization in the medusan Spirocodon saltatrix. Biol. Bull., 99: 412-415.

- - 1970. Morphogenetic aspects of acrosome formation and reaction. In "Advances in Morphogenesis". (M. Abercrombie, J. BrackeT, and T. KING, eds.) 8: 1-39. Academic Press, New York.

Elinson, R. P. 1971. Fertilization of partially jellied and jellyless oocytes of the frog Rana pipiens. J. Exp. Zool, 176: 415-428.

Hinsch, G. W. and W. H. Clark, Jr. 1970 Comparative studies of coelentrate sperms. J. Cell Biol., 47: 88a.

Lunger, P. D. 1971. Early stages of spermatozoon development in the colonial hydroid, Campanularia flexuosa. Zeitschr. f. Zellforsch., 116: 37-51.

Mergner, H. 1957. Die Ei- und Embryonalentwicklung von Eudendrium racemosum. Zool. Jb., Abt. Anat. und Ontog., 76: 63-164.

MrLler, R. L. 1966. Chemotaxis during fertilization in the hydroid Campanularia. J. Exp. Zool., 162: $23-44$.

- 1969 . Preliminary observations on maturation of the female gonangium of Campanularia flexuosa. Biol. Bull., 137: 409-410.

-, 1970 . Sperm migration prior to fertilization in the hydroid Gonothyrea loveni. J. Exp. Zool., 175: 493-504.

- 1922 a. Chemotaxis in animal sperm. In "Behaviour of Microorganisms" (A. PereZMiravete, ed.). (in press), Plenum, London, England.

- - 1972b. Gel filtration of the sperm attractants of some marine hydroids. J. Exp. Zool., 182: in press.

O'RAND, M. G. 1971. In vitro fertilization and capacitation-like interaction in the hydroid Campanularia flexuosa. Biol. Bull., 141 : 398.

- 1972a. Fertilization in the hydroids Campanularia flexuosa Hincks: An in vivo and in vitro study. Thesis, Temple University, Philadelphia. 
1972b. A soluble cell surface material required for spermatozoan-epithelial interaction during fertilization in Campanularia flexuosa. Biol. Bull., 143: 472.

-, $1972 \mathrm{c}$. In vitro fertilization and capacitation-like interaction in the hydroid Campanularia. J. Exp. Zool., 182: in press. , and MilLer, R. 1973. Spermatozoan vesicle loss during penetration of the female gonangium in the hydroid Campanularia flexuosa. Tissue and Cell (submitted).

ShIVERS, A. A. and J. M. JAmes 1971. Fertilization of antiserum inhibited frog eggs with "capacitated" sperm. Biol. Reprod., 5: 229-235.

SUMmers, R. G. 1972. An ultrastructural study of the spermatozoon of Eudendrium racemosum. Zeitschr. f. Zellforsch., 132: 147-166.

TYLER, A. 1949. Properties of fertilizin and related substances of eggs and sperm of some marine animals. Am. Nat., 83: 195-219.

, and B. TYLER 1966. Physiology of fertilization and early development. In "Physiology of Echinodermata" (R. A. Booloorian, ed.) pp. 683-741. John Wiley and Sons, New York.

VAN DE VYVER, G. 1968. Étude du développement des hydraires athecates (gymnoblastiques) à gonophores. II. Formes à actinulas. Arch. de Biol., 79: 327-363.

Weismann, A. 1883. Die Entstehung der Sexualzellen bei den Hydromedusen. Jena. 